\title{
Orchestrating Impartiality: The Impact of "Blind" Auditions on Female Musicians
}

\section{Citation}

Goldin, Claudia, and Cecilia Rouse. 2000. "Orchestrating Impartiality: The Impact of 'Blind' Auditions on Female Musicians." American Economic Review 90 (4) (September): 715-741. doi:10.1257/aer.90.4.715.

\section{Published Version}

doi:10.1257/aer.90.4.715

\section{Permanent link}

http://nrs.harvard.edu/urn-3:HUL.InstRepos:30703974

\section{Terms of Use}

This article was downloaded from Harvard University's DASH repository, and is made available under the terms and conditions applicable to Other Posted Material, as set forth at http:// nrs.harvard.edu/urn-3:HUL.InstRepos:dash.current.terms-of-use\#LAA

\section{Share Your Story}

The Harvard community has made this article openly available.

Please share how this access benefits you. Submit a story.

\section{Accessibility}




\title{
Orchestrating Impartiality: The Impact of "Blind" Auditions on Female Musicians
}

\author{
By Claudia Goldin and Cecilia Rouse*
}

\begin{abstract}
A change in the audition procedures of symphony orchestras-adoption of "blind" auditions with a "screen" to conceal the candidate's identity from the juryprovides a test for sex-biased hiring. Using data from actual auditions, in an individual fixed-effects framework, we find that the screen increases the probability a woman will be advanced and hired. Although some of our estimates have large standard errors and there is one persistent effect in the opposite direction, the weight of the evidence suggests that the blind audition procedure fostered impartiality in hiring and increased the proportion women in symphony orchestras. (JEL J7, J16)
\end{abstract}

Sex-biased hiring has been alleged for many occupations but is extremely difficult to prove. The empirical literature on discrimination, de-

\footnotetext{
* Goldin: Department of Economics, Harvard University, Cambridge, MA 02183; Rouse: Woodrow Wilson School, Princeton University, Princeton, NJ 08544. Rouse acknowledges The National Academy of Education, the NAE Spencer Postdoctoral Fellowship Program, and the Mellon Foundation for financial support. We are indebted to the staff members of the orchestras that gave us access to their audition records and who provided other assistance, and to the musicians who responded to our questionnaire. We are particularly grateful to Joanne Berry, Brigit Carr, Ruth DeSarno, Stefanie Dyson, Josh Feldman, Barbara Haws, Oren Howard, Cindy Hubbard, Carol Jacobs, Lynn Larsen, Bennett McClellan, Stephen Molina, Bill Moyer, Jeffrey Neville, Stephen Novak, Deborah Oberschalp, Stacey Pelinka, Carl Schiebler, Alison Scott-Williams, Robert Sirineck, Harold Steiman, and Brenda Nelson Strauss. We also thank Gretchen Jackson of the University of Michigan School of Music. Rashid Alvi, Brigit Chen, Eric Hilfers, Serena Mayeri, LaShawn Richburg, Melissa Schettini, Thomas Tucker, Linda Tuch, and Lavelle (Yvette) Winfield served as our extremely able research assistants. David Howell of the Princeton University Department of East Asian Studies and Jin Heum Park kindly helped to determine the gender of Japanese and Korean names. We thank them all. We are grateful to our colleagues David Card, Anne Case, David Cutler, Angus Deaton, Hank Farber, Larry Katz, Alan Krueger, David Lee, and Aaron Yelowitz for helpful conversations, and to seminar participants at the School of Industrial and Labor Relations at Cornell University, University of Illinois at ChampaignUrbana, Princeton University, University of Toronto, Harvard University, and Vanderbilt University. We also thank two anonymous referees for comments that have made this a better paper. Any remaining errors are ours. Unfortunately the data used in this article are confidential and may not be made available to other researchers.
}

riving from the seminal contributions of Gary Becker (1971) and Kenneth Arrow (1973), has focused mainly on disparities in earnings between groups (e.g., males and females), given differences in observable productivity-altering characteristics. With the exception of various audit studies (e.g., Genevieve Kenney and Douglas A. Wissoker, 1994; David Neumark et al., 1996) and others, few researchers have been able to address directly the issue of bias in hiring practices. ${ }^{1}$ A change in the way symphony orchestras recruit musicians provides an unusual way to test for sex-biased hiring.

Until recently, the great symphony orchestras in the United States consisted of members who were largely handpicked by the music director. Although virtually all had auditioned for the position, most of the contenders would have been the (male) students of a select

\footnotetext{
${ }^{1}$ An extensive literature exists on occupational segregation by sex and the possible reasons for the large differences in occupations between men and women today and in the past. The debate is ongoing. On the one hand are those who believe that discrimination, either individual or societal in nature, is the driving force, and on the other hand are those who claim the evidence shows women and men sort among occupations on the basis of different tastes for work characteristics. In the former category see Paula England (1982) and England et al. (1988); in the latter group see Solomon W. Polachek (1979) and Randall K. Filer (1989). It should be noted that many other studies (e.g., Ian Ayres and Joel Waldfogel, 1994) have also attempted to measure discrimination in atypical ways.
} 
group of teachers. In an attempt to overcome this seeming bias in the hiring of musicians, most major U.S. orchestras changed their audition policies in the 1970's and 1980's making them more open and routinized. Openings became widely advertised in the union papers, and many positions attracted more than 100 applicants where fewer than 20 would have been considered before. Audition committees were restructured to consist of members of the orchestra, not just the conductor and section principal. The audition procedure became democratized at a time when many other institutions in America did as well.

But democratization did not guarantee impartiality, because favorites could still be identified by sight and through resumes. Another set of procedures was adopted to ensure, or at least give the impression of, impartiality. These procedures involve hiding the identity of the player from the jury. Although they take several forms, we use the terms "blind" and "screen" to describe the group. ${ }^{2}$ The question we pose is whether the hiring process became more impartial through the use of blind auditions. Because we are able to identify sex, but no other characteristics for a large sample, we focus on the impact of the screen on the employment of women. ${ }^{3}$

Screens were not adopted by all orchestras at once. Among the major orchestras, one still does not have any blind round to their audition procedure (Cleveland) and one adopted the screen in 1952 for the preliminary round (Boston Symphony Orchestra), decades before the others. Most other orchestras shifted to blind preliminaries from the early 1970 's to the late 1980 's. The variation in screen adoption at various rounds in the audition process allows us to assess its use as a treatment. ${ }^{4}$

The change in audition procedures with the adoption of the screen allows us to test whether bias exists in its absence. In both our

\footnotetext{
${ }^{2}$ For an article about the blind audition process see The Economist (1996).

${ }^{3}$ The screen may also have opened opportunities for individuals from less-well-known orchestras, those trained outside mainstream institutions, and those from minority groups.

${ }^{4}$ The blind audition procedures bear some resemblance to "double-blind" refereeing in academic journals. See Rebecca Blank (1991) for an assessment of the treatment effect of such refereeing in the American Economic Review.
}

study and studies using audits, the issue is whether sex (or race or ethnicity), apart from objective criteria (e.g., the sound of a musical performance, the content of a resume), is considered in the hiring process. Why sex might make a difference is another matter.

Our data come from two sources: rosters and audition records. Rosters are simply lists of orchestra personnel, together with instrument and position (e.g., principal), found in orchestra programs. The audition records are the actual accounts of the hiring process kept by the personnel manager of the orchestra. Both are described in more detail below.

The audition records we have collected form an uncommon data set. Our sample includes who was advanced and hired from an initial group of contestants and also what happened to approximately two-thirds of the individuals in our data set who competed in other auditions in the sample. There are, to be certain, various data sets containing information on applicant pools and hiring practices (see, e.g., Harry Holzer and David Neumark, 1996). But our data set is unique because it has the complete applicant pool for each of the auditions and links individuals across auditions. Most important for our study is that audition procedures differed across orchestras in known ways and that the majority of the orchestras in our sample changed audition procedure during the period of study. ${ }^{5}$

We find, using our audition sample in an individual fixed-effects framework, that the screen increases the probability a woman will be advanced out of a preliminary round when there is no semifinal round. The screen also greatly enhances the likelihood a female contestant will be the winner in a final round. Using both the roster and auditions samples, and reasonable assumptions, the switch to blind auditions can explain about one-third of the increase in the proportion female among new hires (whereas another onethird is the result of the increased pool of female candidates). Estimates based on the roster sample indicate that blind auditions may account for 25 percent of the increase in the percentage of orchestra musicians who are female.

\footnotetext{
${ }^{5}$ This statement is true for the roster sample. There are only a few orchestras that changed audition procedures during the years of our audition data.
} 


\section{Sex Composition of Orchestras}

Symphony orchestras consist of about 100 musicians and, although the number has varied between 90 to 105 , it is rarely lower or higher. The positions, moreover, are nearly identical between orchestras and over time. As opposed to firms, symphony orchestras do not vary much in size and have virtually identical numbers and types of jobs. Thus we can easily look at the proportion women in an orchestra without being concerned about changes in the composition of occupations and the number of workers. An increase in the number of women from, say, 1 to 10 , cannot arise because the number of harpists (a female-dominated instrument), has greatly expanded. It must be because the proportion female within many groups has increased.

Among the five highest-ranked orchestras in the nation (known as the "Big Five") - the Boston Symphony Orchestra (BSO), the Chicago Symphony Orchestra, the Cleveland Symphony Orchestra, the New York Philharmonic (NYPhil), and the Philadelphia Orchestra-none contained more than 12 percent women until about $1980 .{ }^{6}$ As can be seen in Figure 1A, each of the five lines (giving the proportion female) greatly increases after some point. For the NYPhil, the line steeply ascends in the early 1970's. For the BSO, the turning point appears to be a bit earlier. The percentage female in the NYPhil is currently 35 percent, the highest among all 11 orchestras in our sample after being the lowest (generally at zero) for decades. Thus the increase of women in the nation's finest orchestras has been extraordinary. The increase is even more remarkable because, as we discuss below, turnover in these orchestras is exceedingly low. The proportion of new players who were women must have been, and indeed was, exceedingly high.

Similar trends can be discerned for four other orchestras- the Los Angeles Symphony Orchestra (LA), the San Francisco Philharmonic (SF), the Detroit Symphony Orchestra, and the Pittsburgh Symphony Orchestra

\footnotetext{
${ }^{6}$ The data referred to, and used in Figures 1 to 3, are from orchestral rosters, described in more detail below.
}

(PSO)_ given in Figure $1 \mathrm{~B}^{7}$ The upward trend in the proportion female is also obvious in Figure 1B, although initial levels are higher than in Figure 1A. There is somewhat more choppiness to the graph, particularly during the 1940's. Although we have tried to eliminate all substitute, temporary, and guest musicians, especially during World War II and the Korean War, this was not always possible.

The only way to increase the proportion women is to hire more female musicians and turnover during most periods was low. The number of new hires is graphed in Figure 2 for five orchestras. Because "new hires" is a volatile construct, we use a centered five-year moving average. In most years after the late 1950's, the top-ranked orchestras in the group (Chicago and NYPhil) hired about four musicians a year, whereas the other three hired about six. Prior to 1960 the numbers are extremely high for LA and the PSO, because, it has been claimed, their music directors exercised their power to terminate, at will, the employment of musicians. Also of interest is that the number of new hires trends down, even excluding years prior to 1960 . The important points to take from Figure 2 are that the number of new hires was small after 1960 and that it declined over time.

The proportion female among the new hires must have been sizable to increase the proportion female in the orchestras. Figure 3 shows the trend in the share of women among new hires for four of the "Big Five" (Figure 3A) and four other orchestras (Figure $3 B){ }^{8}$ In both groups the female share of new hires rose over time, at a somewhat steeper rate for the more prestigious orchestras. Since the early 1980's the share female among new hires has been about 35 percent for the BSO and Chicago, and about 50 percent for the NYPhil, whereas before 1970 less than 10 percent of new hires were women. ${ }^{9}$

Even though the fraction of new hires who are female rises at somewhat different times

\footnotetext{
${ }^{7}$ Our roster sample also includes the Metropolitan Opera Orchestra and the St. Louis Symphony.

${ }^{8} \mathrm{~A}$ centered five-year moving average is also used for this variable.

${ }^{9}$ In virtually all cases the share of women among new hires has decreased in the 1990's.
} 


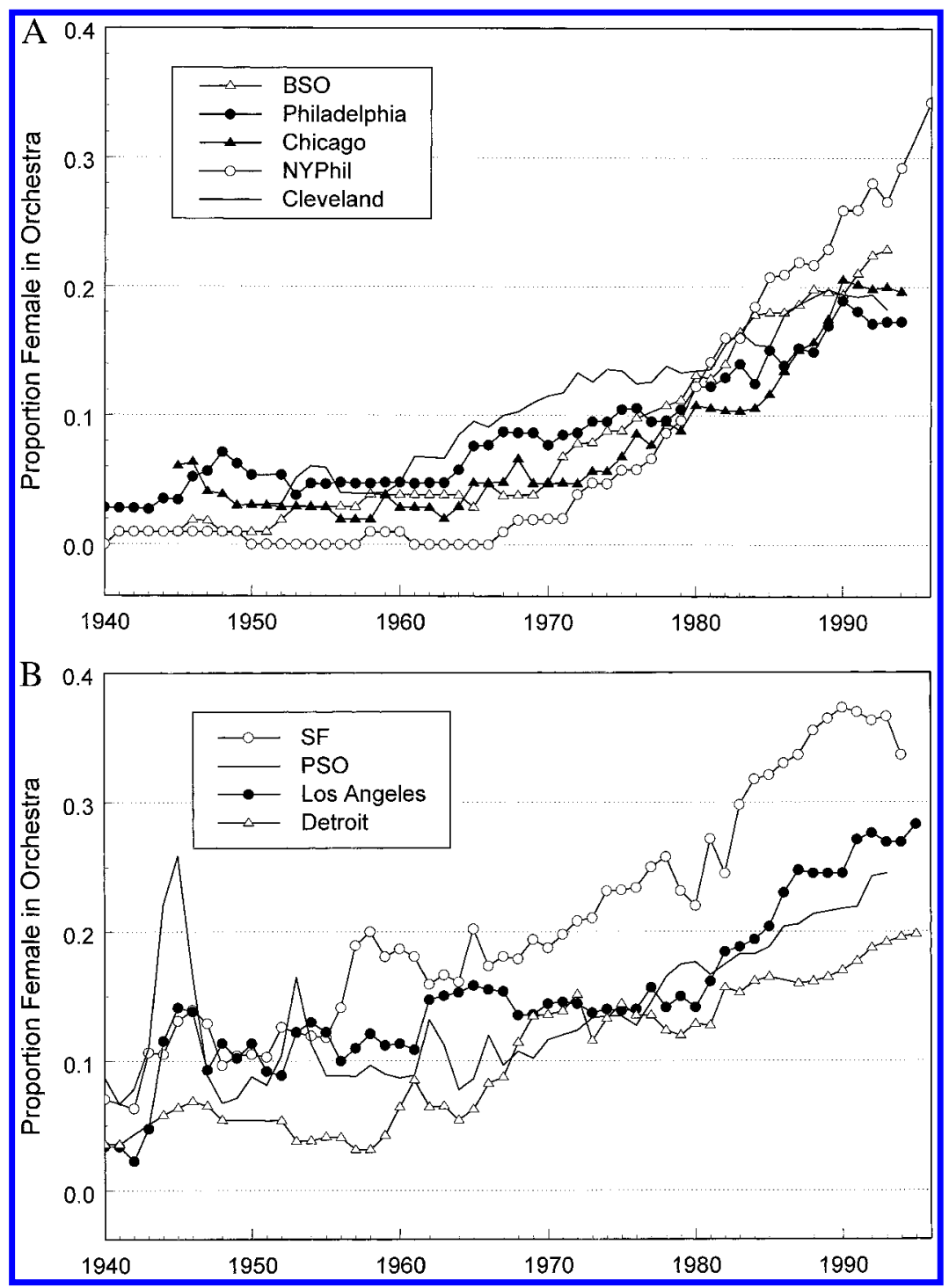

Figure 1. Proportion Female in Nine Orchestras, 1940 to 1990's

A: The "Big Five"; B: Four Others

Source: Roster sample. See text.

across the orchestras, there is a discernible increase for the group as a whole in the late 1970 's to early 1980 's, a time when the labor force participation of women increased generally and when their participation in various professions greatly expanded. The question, therefore, is whether the screen mattered in a direct manner or whether the increase was the result of a host of other factors, including the appearance of impartiality or an increased pool of female contestants coming out of music schools. Because the majority of new hires are in their late twenties and early thirties, the question is whether the most selective music schools were producing considerably more female students in the early 1970's. We currently have information by instrument for only the Juilliard School of Music. With the exception of the brass section, the data, given in Figure 4, do not reveal 


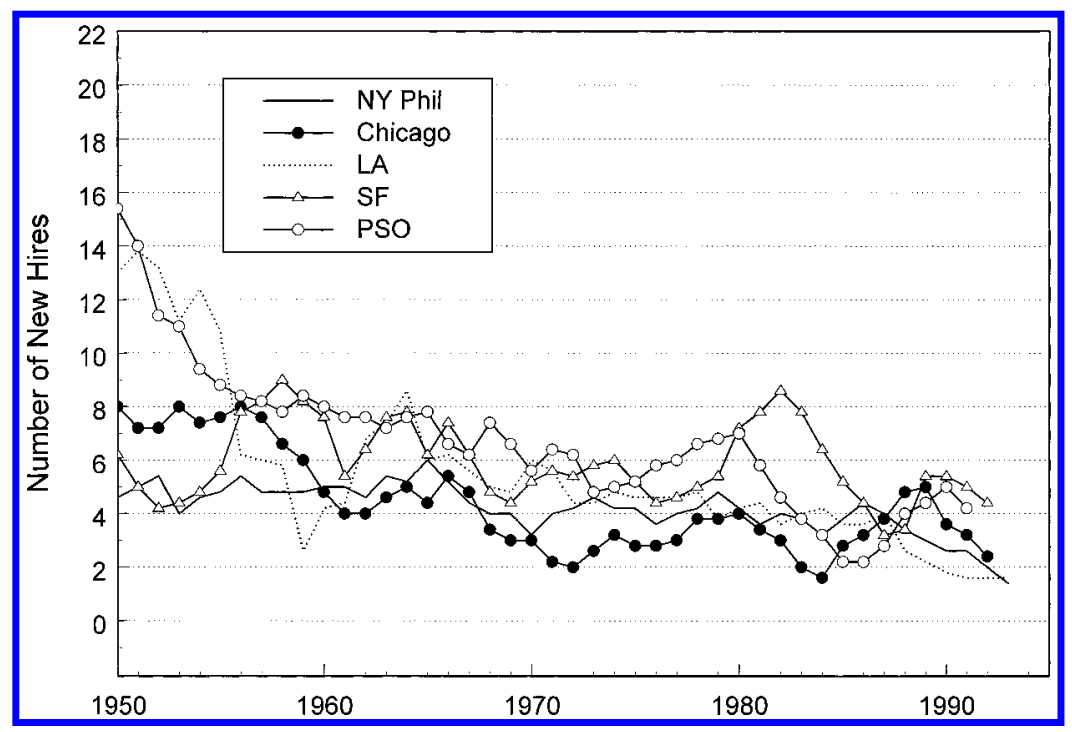

Figure 2. Number of New Hires in Five Orchestras, 1950 to 1990's

Source: Roster sample. See text.

Notes: A five-year centered moving average is used. New hires are musicians who were not with the orchestra the previous year, who remain for at least one additional year, and who were not substitute musicians in the current year.

any sharp breaks in the fraction of all graduates who are female. ${ }^{10}$ Thus, it is not immediately obvious that an expansion in the supply of qualified female musicians explains the marked increase in female symphony orchestra members; it could, therefore, be because of changes in the hiring procedures of orchestras.

But why would changes in audition procedures alter the sex mix of those hired? Many of the most renowned conductors have, at one time or another, asserted that female musicians are not the equal of male musicians. Claims abound in the world of music that "women have smaller techniques than men," "are more temperamental and more likely to demand special attention or treatment," and that "the more women [in an orchestra], the poorer the

\footnotetext{
${ }^{10}$ We also have data on the sex composition of the graduates of the University of Michigan School of Music and Indiana University, but not by instrument. In the Michigan data, both for those receiving the Bachelor of Music (BM) degree and for those receiving the Master of Music (MM) degree, there is no change in the percentage female from 1972 to 1996 . The Indiana University data, for both $\mathrm{BM}$ and MM degrees and excluding voice, piano, guitar, and early instruments, show an increase in the fraction female from 1975 to 1996 . The ratio of females to males was 0.9 in 1975 but 1.2 in 1996.
}

sound." "11 Zubin Mehta, conductor of the Los Angeles Symphony from 1964 to 1978 and of the New York Philharmonic from 1978 to 1990 , is credited with saying, "I just don't think women should be in an orchestra."12 Many European orchestras had, and some continue to have, stated policies not to hire women. ${ }^{13}$ The Vienna Philharmonic has only recently admitted its first female member (a harpist). Female musicians, it can be convincingly argued, have historically faced considerable discrimination. ${ }^{14}$ Thus a blind hiring procedure, such as a screen that conceals the identity of the musician auditioning, could eliminate

${ }^{11}$ Seltzer (1989), p. 215.

${ }^{12}$ Seltzer (1989), p. 215 . According to Seltzer, the fact that new hires at the NYPhil were about 45 percent female during Mehta's tenure as conductor suggests that Mehta's views may have changed.

${ }^{13}$ In comparison with the United Kingdom and the two Germanys, the United States in 1990 had the highest percentage female among its regional symphony orchestras and was a close second to the United Kingdom in the major orchestra category (Jutta J. Allmendinger et al., 1996).

${ }^{14}$ In addition, an African-American cellist (Earl Madison) brought a civil suit against the NYPhil in 1968 alleging that their audition procedures were discriminatory because they did not use a screen. The orchestra was found not guilty of discriminating in hiring permanent musicians, but it was found to discriminate in hiring substitutes. 


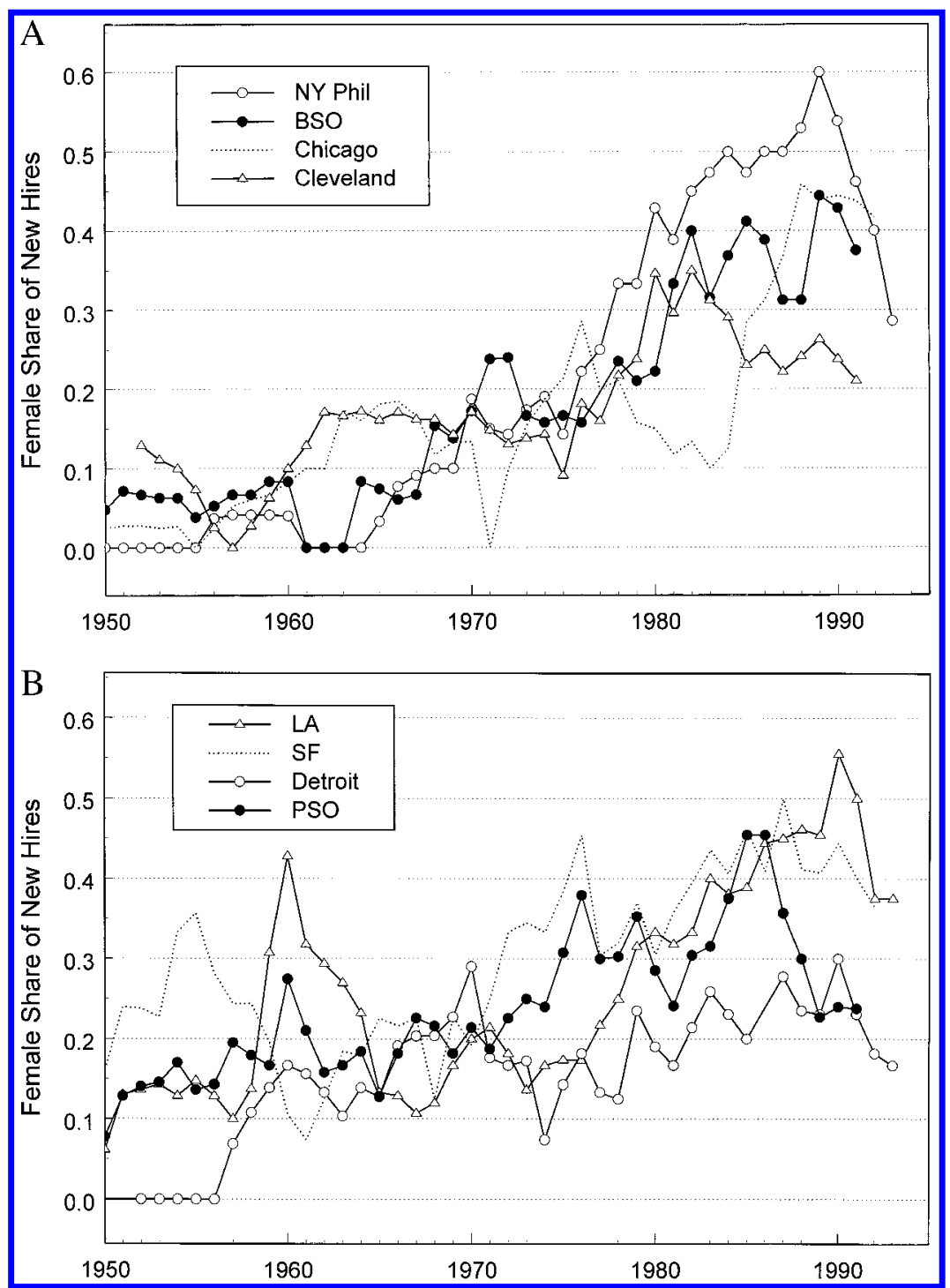

Figure 3. Female Share of New Hires in Eight Orchestras, 1950 to 1990’s A: Four of THE "Big Five"; B: Four Others

Source: Roster sample. See text.

Notes: A five-year centered moving average is used. New hires are musicians who were not with the orchestra the previous year, who remain for at least one additional year, and who were not substitute musicians in the current year.

the possibility of discrimination and increase the number of women in orchestras.

\section{Orchestral Auditions}

To understand the impact of the democratization of the audition procedure and the screen, we must first explain how orchestra auditions are now conducted. After determining that an audition must be held to fill an opening, the orchestra advertises that it will hold an audition. Each audition attracts musicians from across the country and, often, 


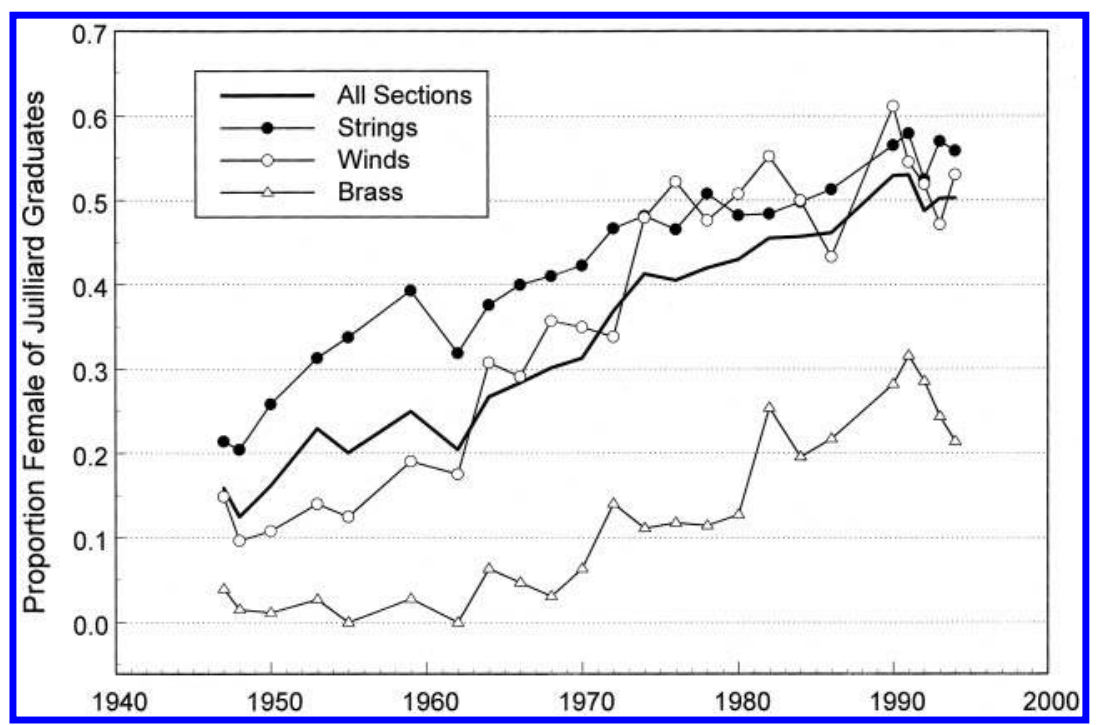

Figure 4. Proportion Female of Juilliard Graduates, Total and by Section: 1947 to 1995

Source: Juilliard Music School files.

from around the world. ${ }^{15}$ Musicians interested in auditioning are required to submit a resume and often a tape of compulsory music (recorded according to specific guidelines) to be judged by members of the orchestra. In some orchestras this prescreening is dispositive; in others the musician has the right to audition live in the preliminary round, even if the audition committee rejects the candidate on the basis of the tape. ${ }^{16}$ All candidates are given, in advance, most of the music they are expected to perform at the live audition.

Live auditions today generally consist of three rounds: preliminary, semifinal, and final. But there is considerable variation. Although all orchestras now have a preliminary round, some have two final rounds and in many there was no semifinal round until the 1980's. The preliminary is generally considered a screening round to eliminate unqualified candidates. As a result,

\footnotetext{
${ }^{15}$ Orchestral auditions, particularly for the nation's most prestigious orchestras, are national if not international, in scope. Many contestants, the vast majority of whom receive no travel reimbursement, travel long distances to audition. The auditions span the fewest number of days possible to minimize hotel charges.

${ }^{16}$ The tape, in this case, provides information to the candidate of his or her likelihood of success, sparing the musician a potentially large travel expense.
}

the committee is free to advance as many, or as few, as they wish. Candidates advanced from the semifinal round are generally considered "acceptable for hire" by the audition committee (which does not include the music director, a.k.a. conductor, until the finals). Again, this means that the committee can advance as many as it wishes. The final round generally results in a hire, but sometimes does not. ${ }^{17}$

In blind auditions (or audition rounds) a screen is used to hide the identity of the player from the committee. ${ }^{18}$ The screens we have seen are either large pieces of heavy (but soundporous) cloth, sometimes suspended from the ceiling of the symphony hall, or look like large room dividers. Some orchestras also roll out a carpet leading to center stage to muffle footsteps that could betray the sex of the candidate. ${ }^{19}$ Each candidate for a blind audition is given a number, and the jury rates the candidate's

\footnotetext{
${ }^{17}$ There is one exception to this general rule. In rare cases when the committee cannot decide between two or three candidates, each is invited to play with the orchestra before the final decision is made.

${ }^{18}$ It may also serve to hide the identity of the committee from the player, although that is not its main function. We use the terms "blind" and "screen" interchangeably.

${ }^{19} \mathrm{Or}$, if a carpet is not placed on the stage, the personnel manager may ask a woman to take off her shoes and he provides the compensating footsteps.
} 
performance next to the number on a sheet of paper. Only the personnel manager knows the mapping from number to name and from name to other personal information. ${ }^{20}$ The names of the candidates are not revealed to the juries until after the last blind round.

Almost all preliminary rounds are now blind. The semifinal round, added as the number of applicants grew, may be blind. Finals are rarely blind and almost always involve the attendance and input of the music director. ${ }^{21}$ Although the music director still wields considerable power, the self-governance that swept orchestras in the 1970 's has served to contain the conductor's authoritarianism. The music director can ignore the audition committee's advice, but does so at greater peril. Once an applicant is chosen to be a member of an orchestra, lifetime tenure is awarded after a brief probationary period. The basis for termination is limited and rarely used. The positions we are analyzing are choice jobs in the musical world. In 1995 the minimum starting base salary for musicians at the BSO was $\$ 1,400$ per week (for a 52-week year), not including recording contracts, soloist fees, overtime and extra service payments, bonuses, and per diem payments for tours and Tanglewood. ${ }^{22}$

Are blind auditions truly blind, or can a trained, accomplished musician identify contestants solely from differences in playing style, just as academics can often identify authors of double-blind papers they get to referee? Unlike double-blind refereeing, for which one sees an

\footnotetext{
${ }^{20}$ The personnel manager is generally a musician who played with the orchestra for some time and knows the players and the conductor well. The duties involve managing the day-to-day work of the orchestra, getting substitute musicians, making travel plans, and arranging the hiring of new musicians.

${ }^{21}$ It is almost always the case that if an orchestra in, say, the spring of 1986 holds a blind preliminary round for a position, it will have all its candidates audition blind in that round and in all other preliminary rounds during that season, should there be any. That is, there is generally no discretion on the part of the jury (and certainly not on the part of the contestant) in terms of the audition procedure, particularly once an audition is underway.

${ }^{22}$ Most of the orchestra contracts in the group we have examined have similar base salaries. Union contracts list only the minimum or base starting salary and minimum increments for seniority. We do not know how many musicians have individually negotiated rates above the stated minimum amounts.
}

entire paper with its distinctive writing style, methodology, sources, and citations, the candidates play only predetermined and brief excerpts from the orchestral repertoire. Each candidate typically has just 5 to 10 minutes to play for the audition committee, particularly in the early rounds. There is little or no room for individuality to be expressed and not much time for it to be detected. ${ }^{23}$ Even when an individual musician is known in advance to be auditioning, jury members often cannot identify that individual. Only the rare, well-known candidate, with an unusually distinctive musical style could conceivably be correctly identified.

The many musicians and personnel managers with whom we have spoken uniformly deny that identification is possible for the vast majority of contestants. They also observe that, although it is tempting to guess the identity of a contestant, particularly in the later rounds, audition committee members, more often than not, find they are wrong. To base a hiring decision on speculation would not be in the best interests of the orchestra. Further, although an individual committee member may believe that he or she knows the identity of a player, it would be rare for the entire committee to be secure in such knowledge. Thus, even if one committee member's vote is swayed by such a belief, the committee's vote must correspond to the consensus view of the player's musical ability for it to determine the outcome. Thus, auditions held with a screen, apart from very few exceptions, are truly blind.

The audition procedures of the 11 orchestras in the roster sample are summarized in Table $1 .{ }^{24}$ Although audition procedures are now part of union contracts, that was not the case in the more distant past and the procedures were not apparently recorded in any surviving documents. We gathered information on these procedures from various sources, including union contracts, interviews with personnel managers, archival documents on auditions, and a mail survey we conducted of orchestral musicians concerning the proce-

\footnotetext{
${ }^{23}$ Also, there is generally not a standing audition committee that might become familiar with the musicians who audition frequently.

${ }^{24}$ We identify the orchestras by letter, rather than by name, to preserve confidentiality of the audition sample.
} 
Table 1 -Orchestra Audition Procedure Summary Table

\begin{tabular}{|c|c|c|c|}
\hline Orchestra & Preliminaries & Semifinals & Finals \\
\hline A & Blind since 1973 & $\begin{array}{l}\text { Blind (varies) since } \\
1973\end{array}$ & Not blind \\
\hline B & Blind since at least 1967 & Use of screen varies & $\begin{array}{l}\text { Blind } 1967-1969 \text {; since } \\
\text { winter } 1994\end{array}$ \\
\hline $\mathrm{C}$ & $\begin{array}{l}\text { Blind since at least } 1979 \\
\text { (definitely after 1972) }\end{array}$ & $\begin{array}{l}\text { Not blind: 1991-present } \\
\text { Blind: 1984-1987 }\end{array}$ & Not blind \\
\hline $\mathrm{D}$ & Blind since 1986 & $\begin{array}{l}\text { Blind since 1986; varies } \\
\text { until } 1993\end{array}$ & $\begin{array}{l}\text { 1st part blind since 1993; } \\
\text { 2nd part not blind }\end{array}$ \\
\hline $\mathrm{E}$ & Use of screen varies until 1981 & Use of screen varies & Not blind \\
\hline $\mathrm{F}$ & Blind since at least 1972 & $\begin{array}{l}\text { Blind since at least } \\
1972\end{array}$ & Blind since at least 1972 \\
\hline G & Blind since 1986 & Use of screen varies & Not blind \\
\hline $\mathrm{H}$ & Blind since 1970 & Not blind & Not blind \\
\hline I & Blind since 1979 & Blind since 1979 & Blind since fall 1983 \\
\hline $\mathrm{J}$ & Blind since 1952 & Blind since 1952 & Not blind \\
\hline $\mathrm{K}$ & Not blind & Not blind & Not blind \\
\hline
\end{tabular}

Notes: The 11 orchestras (A through K) are those in the roster sample described in the text. A subset of eight form the audition sample (also described in the text). All orchestras in the sample are major big-city U.S. symphony orchestras and include the "Big Five."

Sources: Orchestra union contracts (from orchestra personnel managers and libraries), personal conversations with orchestra personnel managers, and our mail survey of current orchestra members who were hired during the probable period of screen adoption.

dures employed during the audition that won them their current position.

An obvious question to ask is whether the adoption of the screen is endogenous. Of particular concern is that more meritocratic orchestras adopted blind auditions earlier, producing the spurious result that the screen increased the likelihood that women were hired. ${ }^{25}$ We estimate a probit model of screen adoption by year, conditional on an orchestra's not previously having adopted the screen (an orchestra exits the exercise once it adopts the screen). Two time-varying covariates are included to assess commonly held notions about screen adoption: the proportion female (lagged) in the orchestra, and a measure of tenure (lagged) of then-current orchestra members. Tenure is included because personnel managers maintain the screen was advocated more by younger players.

As the proportion female in an orchestra increases, so does the likelihood of screen adoption in the preliminary round, as can be seen in

\footnotetext{
${ }^{25}$ Note, however, it is unlikely that the orchestras that sought to hire more women chose to adopt the screen earlier since the best way to increase the number of women in the orchestra is to have not-blind auditions (so that one could be sure to hire more women).
}

columns (1) and (2) in Table 2, although the effects are very small and far from statistically significant. ${ }^{26}$ We estimate a similar effect when we assess the role of female presence on the adoption of blind finals [see column (3)]. The impact of current tenure, measured by the proportion with less than six years with the orchestra, is-contrary to general belief-negative and the results do not change controlling for whether the orchestra is one of the "Big Five." 27 In all, it appears that orchestra sex composition had little influence on screen adoption, although the stability of the personnel may have increased its likelihood. ${ }^{28}$

\footnotetext{
${ }^{26}$ An increase in the proportion female from 0 to 0.35 , the largest for any of the orchestras (see Figure 1), would enhance the likelihood of adopting the screen in the preliminary round by a mere 0.0021 percentage points.

${ }^{27}$ Our measure of tenure begins at the first date for which we have rosters, but not earlier than 1947. Tenure then cumulates for each member until the individual exits the orchestra. Because tenure will increase for all orchestras with time, we use the proportion of all members with fewer than six years of tenure.

${ }^{28}$ A change in conductor could also have led to a change in the audition policy, but we find no supporting evidence. For example, current players contend that Charles Munch had complete authority in hiring at the BSO before 1952 . The BSO adopted the screen in 1952, but Munch was
} 
TABle 2-Estimated Probit Models FOR THE USE OF A SCREEN

\begin{tabular}{|c|c|c|c|}
\hline & \multicolumn{2}{|c|}{ Preliminaries blind } & \multirow{2}{*}{$\begin{array}{c}\text { Finals } \\
\text { blind }\end{array}$} \\
\hline & (1) & $(2)$ & \\
\hline \multirow[t]{3}{*}{$(\text { Proportion female })_{t-1}$} & 2.744 & 3.120 & 0.490 \\
\hline & $(3.265)$ & $(3.271)$ & (1.163) \\
\hline & {$[0.006]$} & [0.004] & [0.011] \\
\hline \multirow{3}{*}{$\begin{array}{l}\text { (Proportion of orchestra } \\
\text { personnel with }<6 \\
\text { years tenure) })_{t-1}\end{array}$} & -26.46 & -28.13 & -9.467 \\
\hline & $(7.314)$ & $(8.459)$ & (2.787) \\
\hline & {$[-0.058]$} & {$[-0.039]$} & {$[-0.207]$} \\
\hline \multirow[t]{3}{*}{ "Big Five" orchestra } & & 0.367 & \\
\hline & & $(0.452)$ & \\
\hline & & {$[0.001]$} & \\
\hline pseudo $I$ & 0.178 & 0.193 & 0.050 \\
\hline Number of observations & 294 & 294 & 434 \\
\hline
\end{tabular}

Notes: The dependent variable is 1 if the orchestra adopts a screen, 0 otherwise. Huber standard errors (with orchestra random effects) are in parentheses. All specifications include a constant. Changes in probabilities are in brackets. "Proportion female" refers to the entire orchestra. "Tenure" refers to years of employment in the current orchestra. "Big Five" includes Boston, Chicago, Cleveland, New York Philharmonic, and Philadelphia. The data begin in 1947 and an orchestra exits the exercise once it adopts the screen. The unit of observation is an orchestra-year.

Source: Eleven-orchestra roster sample. See text.

\section{The Role of Blind Auditions on the Audition and Hiring Process}

\section{A. Data and Methods}

Audition Records.-We use the actual audition records of eight major symphony orchestras obtained from orchestra personnel managers and the orchestra archives. The records are highly confidential and occasionally contain remarks (including those of the conductor) about musicians currently with the orchestra. To preserve the full confidentiality of the records, we have not revealed the names of the orchestras in our sample.

Although availability differs, taken together we obtained information on auditions dating from the late 1950's through 1995 . Typically, the records are lists of the names of individuals

conductor from 1949 to 1962 . Our inability to explain the timing of screen adoption may result from our lack of intimate knowledge of the musical world, although it is also difficult to explain blind refereeing policy among economics journals (see the list in Blank, 1991). who attended the auditions, with notation near the names of those advanced to the next round. For the preliminary round, this would indicate advancement to either the semifinal or final round. Another list would contain the names of the semifinalists or finalists with an indication of who won the audition. ${ }^{29}$ From these records, we recorded the instrument and position (e.g., section, principal, substitute) for which the audition was held. We also know whether the individual had an "automatic" placement in a semifinal or final round. Automatic placement occurs when a musician is already known to be above some quality cutoff and is invited to compete in a semifinal or final round. ${ }^{30} \mathrm{We}$ also recorded whether the individual was advanced to the next round of the current audition.

We rely on the first name of the musicians to determine sex. For most names establishing sex was straightforward. ${ }^{31}$ Sexing the Japanese and Korean names was equally straightforward, at least for our Japanese and Korean consultants. For more difficult cases, we checked the names in three baby books (Connie Lockhard Ellefson, 1990; Alfred J. Kolatch, 1990; Bruce Lansky, 1995). If the name was listed as male- or female-only, we considered the sex known. The gender-neutral names (e.g., Chris, Leslie, and Pat) and some Chinese names (for which sex is indeterminate in the absence of Chinese characters) remained ambiguous. Using these procedures, we were able to determine the sex of 96 percent of our audition sample. ${ }^{32}$ We later assess the impact that sex misclassification may have on our results.

In constructing our analysis sample, we exclude incomplete auditions, those in which there were no women (or only women) competing, rounds from which no one was advanced, and the second final round, if one exists, for which

\footnotetext{
${ }^{29}$ In rare cases, we have additional information on the finalists, such as resumes.

${ }^{30}$ The person will be known to be above a quality cutoff either because the individual is a current member of a comparable orchestra or because the person was a semifinalist or finalist in a previous audition.

${ }^{31}$ For 13 percent of the contestants, sex was confirmed by personnel managers, resumes, or audition summary sheets.

${ }^{32}$ Most of the remainder were sexed using census data by assigning to them the dominant sex of individuals with their first name.
} 
Table 3-Descriptive Statistics About Auditions, by Year and Round of Audition

\begin{tabular}{|c|c|c|c|c|c|c|c|c|}
\hline Year & $\begin{array}{c}\text { Number of } \\
\text { auditions }\end{array}$ & $\begin{array}{l}\text { Proportion } \\
\text { female }\end{array}$ & $\begin{array}{c}\text { Number of } \\
\text { musicians }\end{array}$ & $\begin{array}{l}\text { Number of } \\
\text { auditions }\end{array}$ & $\begin{array}{l}\text { Proportion } \\
\text { female }\end{array}$ & $\begin{array}{c}\text { Number of } \\
\text { musicians }\end{array}$ & $\begin{array}{l}\text { Number of } \\
\text { auditions }\end{array}$ & $\begin{array}{c}\text { Proportion } \\
\text { female }\end{array}$ \\
\hline & & & \multicolumn{3}{|c|}{ Completely blind auditions } & \multicolumn{3}{|c|}{ Not completely blind auditions } \\
\hline All & 254 & $\begin{array}{c}0.367 \\
(0.013)\end{array}$ & $\begin{array}{l}43.4 \\
(3.13)\end{array}$ & 60 & $\begin{array}{c}0.393 \\
(0.029)\end{array}$ & $\begin{array}{l}38.1 \\
(1.74)\end{array}$ & 194 & $\begin{array}{c}0.359 \\
(0.015)\end{array}$ \\
\hline Pre-1970 & 10 & $\begin{array}{c}0.187 \\
(0.042)\end{array}$ & & & & $\begin{array}{l}16.3 \\
(2.27)\end{array}$ & 10 & $\begin{array}{c}0.187 \\
(0.042)\end{array}$ \\
\hline 1970-1979 & 69 & $\begin{array}{c}0.329 \\
(0.026)\end{array}$ & & & & $\begin{array}{l}31.4 \\
(2.10)\end{array}$ & 69 & $\begin{array}{c}0.329 \\
(0.026)\end{array}$ \\
\hline 1980-1989 & 102 & $\begin{array}{c}0.394 \\
(0.019)\end{array}$ & $\begin{array}{l}42.5 \\
(4.29)\end{array}$ & 33 & $\begin{array}{c}0.375 \\
(0.034)\end{array}$ & $\begin{array}{l}39.6 \\
(2.73)\end{array}$ & 69 & $\begin{array}{c}0.403 \\
(0.022)\end{array}$ \\
\hline $1990+$ & 73 & $\begin{array}{c}0.390 \\
(0.027)\end{array}$ & $\begin{array}{l}44.6 \\
(4.64)\end{array}$ & 27 & $\begin{array}{c}0.415 \\
(0.049)\end{array}$ & $\begin{array}{l}50.6 \\
(4.52)\end{array}$ & 46 & $\begin{array}{c}0.375 \\
(0.033)\end{array}$ \\
\hline Round & & & & $\begin{array}{l}\text { Blind } \\
\text { rounds }\end{array}$ & & & $\begin{array}{c}\text { Not-blind } \\
\text { rounds }\end{array}$ & \\
\hline \multicolumn{9}{|l|}{$\begin{array}{l}\text { Preliminaries, } \\
\text { without }\end{array}$} \\
\hline semifinals & 170 & $\begin{array}{c}0.357 \\
(0.015)\end{array}$ & $\begin{array}{l}34.3 \\
(1.87)\end{array}$ & 125 & $\begin{array}{c}0.367 \\
(0.017)\end{array}$ & $\begin{array}{l}24.7 \\
(2.33)\end{array}$ & 45 & $\begin{array}{c}0.327 \\
(0.029)\end{array}$ \\
\hline \multicolumn{9}{|l|}{$\begin{array}{l}\text { Preliminaries, } \\
\text { with }\end{array}$} \\
\hline semifinals & 137 & $\begin{array}{c}0.396 \\
(0.019)\end{array}$ & $\begin{array}{l}45.5 \\
(2.54)\end{array}$ & 134 & $\begin{array}{c}0.395 \\
(0.019)\end{array}$ & $\begin{array}{c}49.3 \\
(17.0)\end{array}$ & 3 & $\begin{array}{c}0.425 \\
(0.205)\end{array}$ \\
\hline Semifinals & 114 & $\begin{array}{c}0.415 \\
(0.019)\end{array}$ & $\begin{array}{l}12.3 \\
(0.649)\end{array}$ & 89 & $\begin{array}{c}0.404 \\
(0.022)\end{array}$ & $\begin{array}{l}10.4 \\
(1.21)\end{array}$ & 25 & $\begin{array}{c}0.455 \\
(0.043)\end{array}$ \\
\hline Finals & 167 & $\begin{array}{c}0.430 \\
(0.016)\end{array}$ & $\begin{array}{l}4.93 \\
(0.448)\end{array}$ & 28 & $\begin{array}{c}0.472 \\
(0.040)\end{array}$ & $\begin{array}{l}7.12 \\
(0.310)\end{array}$ & 130 & $\begin{array}{c}0.422 \\
(0.017)\end{array}$ \\
\hline
\end{tabular}

Notes: The unit of observation for the top portion is the audition, whereas it is the round for the bottom portion (e.g., proportion female in the top portion of the table is averaged across the auditions). Standard errors are in parentheses.

Source: Eight-orchestra audition sample. See text.

the candidates played with the orchestra. ${ }^{33}$ In addition, we generally consider each round of the audition separately. These sample restrictions exclude 294 rounds (199 contained no women) and 1,539 individuals. Our final analysis sample has 7,065 individuals and 588 audition rounds (from 309 separate auditions) resulting in 14,121 person-rounds and an average of 2.0 rounds per musician. ${ }^{34}$

As can be seen in the bottom portion of Table 3, 259, or 84 percent, of our 307 preliminary rounds were blind, 78 percent of the 114 semifinals were blind, but just 17 percent of the 167 final rounds were blind. Most of our audition sample is for the period after 1970. The blind preliminaries contained 40

\footnotetext{
${ }^{33}$ Although the results are unaffected, harp auditions are excluded because it has typically been a female-dominated instrument.

${ }^{34}$ See Table A1 for descriptive statistics.
}

candidates on average, whereas those without the screen had 26. Women were about 37 percent of all preliminary candidates but 43 percent of finalists, and the difference holds for both the blind and not-blind auditions. The percentage female among all candidates increased over time, from 33 percent in the 1970 to 1979 period to 39 percent in the post-1990 years (see upper portion).

Roster Data.-Our second source of information comes from the final results of the audition process, the orchestra personnel rosters. We collected these data from the personnel page of concert programs, one each year for eleven major symphony orchestras. These records are in the public domain and thus we have used the orchestra names in the graphs containing those data alone. As opposed to the auditionees, we were able to confirm the sex of the players with the orchestra personnel managers and 
archivists. We considered a musician to be new to the orchestra in question if he or she had not previously been a regular member of that orchestra (i.e., we did not count returning members as new). We excluded, when possible, temporary and substitute musicians, as well as harpists and pianists. Our final sample for 1970 to 1996 has 1,128 new orchestra members (see Table A2).

Econometric Framework.-We take advantage of the variation that exists across orchestras, time, and audition round to identify the effect of the screens on the likelihood that a female is advanced from one round to the next and ultimately hired. The probability that individual $i$ is advanced (or hired) from an audition at orchestra $j$, in year $t$, from round $r$, is a function of the individual's sex $(F)$, whether a screen is used $(B)$, and other individual $(X)$ and orchestral $(Z)$ factors, that is:

$$
P_{i j t r}=f\left(X_{i t}, F_{i}, B_{j t r}, Z_{j t r}\right) .
$$

The screen, it will be recalled from Table 1, varies across orchestra, time, and audition round. Orchestras adopted the screen in different years. Some used the screen in the preliminary round only, whereas others used the screen for the entire audition process. We use this variation to estimate a differences-in-differences strategy. In linear form, we write

$$
\begin{aligned}
P_{i j t r}= & \alpha+\beta F_{i}+\gamma B_{j t r}+\delta\left(F_{i} \times B_{j t r}\right) \\
& +X_{i t} \theta_{1}+Z_{j t r} \theta_{2}+\varepsilon_{i j t r}
\end{aligned}
$$

The coefficient on $B_{j t r}, \gamma$, identified from the men who audition with a screen, controls for whether all individuals are more or less likely to be advanced from a blind than from a not-blind audition. Thus the parameter of interest is that on the interaction between $F_{i}$ and $B_{j t r}, \delta$, which measures the change in the probability that a woman will be advanced if a screen is used, relative to her auditioning without a screen (after accounting for other blind audition effects). We also test whether the use of the screen eliminates sex differences in the likelihood an individual is advanced from one round to the next. Because no restrictions exist on the number of individuals advanced from the preliminary and semifinal rounds, there is no zero-sum game between men and women for these rounds.

\section{B. The Effect of the Screen on the Likelihood of Being Advanced}

Tabulations and Regression Results With and Without Individual Fixed Effects.-The raw data in Tables 4 and 5 can reveal the impact on women of changes in the audition process and provide an important introduction to the data. We demonstrate that in the absence of a variable for orchestral "ability," women fare less well in blind auditions than otherwise. But if the orchestral "ability" of the candidate is held fixed, the screen provides an unambiguous and substantial benefit for women in almost all audition rounds.

Table 4 gives the success rate by sex, round of audition, and over time. We define "relative female success" as the proportion of women advanced (or hired) minus the proportion of men advanced (or hired). The relative success of female candidates appears worse for blind than for not-blind auditions and this finding also holds for each round of the audition process. One interpretation of this result is that the adoption of the screen lowered the average quality of female auditionees in the blind auditions. Only if we can hold quality constant can we identify the true impact of the screen.

Because we have the names of the candidates, we are able to link their success in one audition to that in another. (In our sample, 24 percent of the individuals competed in more than one audition.) In Table 5 we report audition success statistics, by round and overall, for musicians who appear more than once in our sample and for whom at least one audition (or round) was blind and one was not blind. The evidence tells a very different story from that in Table 4, and taken together they suggest that blind auditions expanded the pool of female applicants to include more who were less qualified. When we limit the sample to those who auditioned both with and without a screen, the success rate for women competing in blind auditions is almost always higher than in those that were not blind. 
Table 4-Average Success at Auditions by Sex, Year, and Round of Audition

\begin{tabular}{|c|c|c|c|}
\hline \multirow[b]{2}{*}{ Year } & \multicolumn{3}{|c|}{ Relative female success } \\
\hline & All auditions & $\begin{array}{l}\text { Completely blind } \\
\text { auditions }\end{array}$ & $\begin{array}{c}\text { Not completely blind } \\
\text { auditions }\end{array}$ \\
\hline \multirow[t]{2}{*}{ All } & -0.001 & -0.022 & 0.006 \\
\hline & $(0.008)$ & $(0.012)$ & $(0.010)$ \\
\hline \multirow[t]{2}{*}{ Pre-1970 } & 0.053 & & 0.053 \\
\hline & $(0.115)$ & & $(0.115)$ \\
\hline \multirow[t]{2}{*}{ 1970-1979 } & 0.001 & & 0.001 \\
\hline & $(0.021)$ & & $(0.021)$ \\
\hline \multirow[t]{2}{*}{ 1980-1989 } & -0.006 & -0.039 & 0.010 \\
\hline & $(0.009)$ & $(0.016)$ & $(0.009)$ \\
\hline \multirow[t]{2}{*}{$1990+$} & -0.003 & -0.001 & -0.003 \\
\hline & $(0.010)$ & $(0.017)$ & $(0.013)$ \\
\hline Round & All rounds & Blind rounds & Not-blind rounds \\
\hline \multirow{2}{*}{ Preliminaries, without semifinals } & -0.032 & -0.048 & 0.012 \\
\hline & $(0.019)$ & $(0.021)$ & $(0.040)$ \\
\hline \multirow{2}{*}{ Preliminaries, with semifinals } & -0.048 & -0.052 & 0.116 \\
\hline & $(0.016)$ & $(0.016)$ & $(0.228)$ \\
\hline \multirow[t]{2}{*}{ Semifinals } & -0.030 & -0.059 & 0.071 \\
\hline & $(0.038)$ & $(0.044)$ & $(0.080)$ \\
\hline \multirow[t]{2}{*}{ Finals } & 0.009 & -0.028 & 0.016 \\
\hline & $(0.036)$ & $(0.102)$ & $(0.038)$ \\
\hline
\end{tabular}

Notes: For the top part of the table "success" is a "hire," whereas for the bottom portion "success" is advancement from one stage of an audition to the next. The unit of observation for the top portion is the audition, whereas it is the round for the bottom portion (e.g., relative female success in the top portion of the table is averaged across the auditions). Standard errors are in parentheses. "Relative female success" is the proportion of women advanced (or hired) minus the proportion of men advanced (or hired). By hired, we mean those who were advanced from the final round out of the entire audition. Source: Eight-orchestra audition sample. See text.

Take the preliminary round with no semifinals, for example, in Table 5. In the blind auditions 28.6 percent of the women are advanced, as are 20.2 percent of the men. But in the not-blind column, just 19.3 percent of the women are advanced, although 22.5 percent of the men are. Even though a woman has a small advantage over a man when the screen is used (by 8.4 percentage points), her success rate, relative to that of a man, is increased by 11.6 percentage points above that in the notblind regime. Note that because these are the same women, Table 5 suggests that a woman enhances her own success rate by 9.3 percentage points by entering a blind preliminary round. Not only do these differences suggest that women are helped by the screen, the differences are large relative to the average rate of success. ${ }^{35}$

Women's success is also enhanced by the

\footnotetext{
${ }^{35}$ Because of the infrequency of position availability, it is unlikely there was much gaming by women (e.g., trying out only for blind auditions), although the change in the
}

screen in the finals and for the overall audition (termed "hired" in the table). For the finals, a woman's success rate is increased by 14.8 percentage points moving to blind auditions $(23.5-8.7)$ and is enhanced by a hefty 28.1 percentage points above that of men. All success rates are very low for auditions as a whole, but the female success rate is 1.6 times higher (increasing from 0.017 to 0.027 ) for blind than for not-blind auditions. The only anomalous result in the table concerns the semifinals, to which we return later. We now show that these results stand up to the controls we can add, including the year of the audition and the instrument. $^{36}$

general environment of auditions could have altered the pool of contestants.

${ }^{36} \mathrm{We}$ do not discuss the regression analog to Table 4 , that is, the analysis without individual fixed effects, because we have firmly established that individual fixed effects matter. Table A3 shows the results of regressions 
Table 5-Average Success at Auditions by Sex and Stage of Audition for the Subset of Musicians Who Auditioned Both Blind and Not Blind

\begin{tabular}{|c|c|c|c|c|}
\hline & \multicolumn{2}{|c|}{ Blind } & \multicolumn{2}{|c|}{ Not blind } \\
\hline & $\begin{array}{l}\text { Proportion } \\
\text { advanced }\end{array}$ & $\begin{array}{l}\text { Number of } \\
\text { person-rounds }\end{array}$ & $\begin{array}{c}\text { Proportion } \\
\text { advanced }\end{array}$ & $\begin{array}{c}\text { Number of } \\
\text { person-rounds }\end{array}$ \\
\hline & \multicolumn{4}{|c|}{ Preliminaries without semifinals } \\
\hline Women & $\begin{array}{c}0.286 \\
(0.043)\end{array}$ & 112 & $\begin{array}{c}0.193 \\
(0.041)\end{array}$ & 93 \\
\hline Men & $\begin{array}{c}0.202 \\
(0.026)\end{array}$ & 247 & $\begin{array}{c}0.225 \\
(0.031)\end{array}$ & 187 \\
\hline & \multicolumn{4}{|c|}{ Preliminaries with semifinals } \\
\hline Women & $\begin{array}{c}0.200 \\
(0.092)\end{array}$ & 20 & $\begin{array}{c}0.133 \\
(0.091)\end{array}$ & 15 \\
\hline \multirow[t]{2}{*}{ Men } & $\begin{array}{c}0.083 \\
(0.083)\end{array}$ & \multirow[t]{2}{*}{12} & $\begin{array}{c}0.000 \\
(0.000)\end{array}$ & \multirow[t]{2}{*}{8} \\
\hline & & & & \\
\hline Women & $\begin{array}{c}0.385 \\
(0.061)\end{array}$ & 65 & $\begin{array}{c}0.568 \\
(0.075)\end{array}$ & 44 \\
\hline \multirow[t]{2}{*}{ Men } & $\begin{array}{c}0.368 \\
(0.059)\end{array}$ & \multirow[t]{2}{*}{68} & $\begin{array}{c}0.295 \\
(0.069)\end{array}$ & \multirow[t]{2}{*}{44} \\
\hline & & & & \\
\hline Women & $\begin{array}{c}0.235 \\
(0.106)\end{array}$ & 17 & $\begin{array}{c}0.087 \\
(0.060)\end{array}$ & 23 \\
\hline \multirow[t]{2}{*}{ Men } & $\begin{array}{c}0.000 \\
(0.000)\end{array}$ & \multirow[t]{2}{*}{12} & $\begin{array}{c}0.133 \\
(0.091)\end{array}$ & \multirow[t]{2}{*}{15} \\
\hline & & & & \\
\hline Women & $\begin{array}{c}0.027 \\
(0.008)\end{array}$ & 445 & $\begin{array}{c}0.017 \\
(0.005)\end{array}$ & 599 \\
\hline Men & $\begin{array}{c}0.026 \\
(0.005)\end{array}$ & 816 & $\begin{array}{c}0.027 \\
(0.005)\end{array}$ & 1102 \\
\hline
\end{tabular}

Notes: The unit of observation is a person-round. Standard errors are in parentheses. For the round in question, only musicians who auditioned more than once and who auditioned at least once behind a screen and at least once without a screen are included. "Hired" means those who were advanced from the final round out of the entire audition. Blind in the "hired" category means for all rounds. Not blind in the "hired" category means that at least one round was not blind. This difference in the definition of what constitutes a "blind" round or audition is one reason why the number of observations in the first four panels is less than the number of observations in the "hired" panel. The number of observations also differ because we exclude auditions or rounds in which no individual is advanced or in which there are only women or no women. Finally, unlike in subsequent tables, we exclude a few candidates for whom we could not determine or impute their sex. Note that the binding constraint for the preliminaries is the not-blind category, for which we have only one orchestra. The binding constraint in the "hired" category are the blind auditions, for which we have (at most) three orchestras. Musicians can appear more than once in either the blind or not-blind categories.

Source: Eight-orchestra audition sample. See text.

The results given in Table 6 are the regression analogs to the raw tabulations in Table $5 .{ }^{37}$ Because the effect of the blind procedure

comparable to those in Table 6 but without individual fixed effects.

${ }^{37}$ In the (total) subsample of individuals auditioning both with and without a screen, all eight orchestras in our audition sample are represented, and seven of the orchestras changed audition policy during our sample time frame. The sample sizes in Table 6 are considerably larger than those in could differ by the various rounds in the audition process, we divide audition rounds into the three main rounds (preliminary, semifinal, and final) and also separate the preliminaries into those that were followed by a semifinal

Table 5. The reason is that the regressions in Table 6 include all individuals whether or not they auditioned more than once, whereas Table 5 includes only those who auditioned at least twice, blind and not blind. 
Table 6-Linear Probability Estimates of the Likelihood of Being Advanced: with Individual Fixed EfFects

\begin{tabular}{|c|c|c|c|c|c|c|c|c|}
\hline & \multicolumn{4}{|c|}{ Preliminaries } & \multirow{2}{*}{\multicolumn{2}{|c|}{ Semifinals }} & \multirow{2}{*}{\multicolumn{2}{|c|}{ Finals }} \\
\hline & \multicolumn{2}{|c|}{$\begin{array}{c}\text { Without } \\
\text { semifinals }\end{array}$} & \multicolumn{2}{|c|}{ With semifinals } & & & & \\
\hline & $(1)$ & $(2)$ & (3) & (4) & $(5)$ & $(6)$ & $(7)$ & $(8)$ \\
\hline Blind & $\begin{array}{r}-0.017 \\
(0.039)\end{array}$ & $\begin{array}{c}0.003 \\
(0.046)\end{array}$ & $\begin{array}{c}0.109 \\
(0.172)\end{array}$ & $\begin{array}{c}0.224 \\
(0.242)\end{array}$ & $\begin{array}{c}0.026 \\
(0.089)\end{array}$ & $\begin{array}{c}0.102 \\
(0.096)\end{array}$ & $\begin{array}{r}-0.154 \\
(0.150)\end{array}$ & $\begin{array}{r}-0.060 \\
(0.149)\end{array}$ \\
\hline Female $\times$ Blind & $\begin{array}{c}0.125 \\
(0.068)\end{array}$ & $\begin{array}{l}0.111 \\
(0.067)\end{array}$ & $\begin{array}{c}0.013 \\
(0.215)\end{array}$ & $\begin{array}{r}-0.025 \\
(0.251)\end{array}$ & $\begin{array}{r}-0.179 \\
(0.126)\end{array}$ & $\begin{array}{r}-0.235 \\
(0.133)\end{array}$ & $\begin{array}{c}0.308 \\
(0.196)\end{array}$ & $\begin{array}{c}0.331 \\
(0.181)\end{array}$ \\
\hline Number of auditions attended & & $\begin{array}{r}-0.020 \\
(0.014)\end{array}$ & & $\begin{array}{c}0.010 \\
(0.010)\end{array}$ & & $\begin{array}{c}0.015 \\
(0.030)\end{array}$ & & $\begin{array}{c}0.126 \\
(0.028)\end{array}$ \\
\hline Years since last audition & & $\begin{array}{c}-0.005 \\
(0.007)\end{array}$ & & $\begin{array}{r}-0.006 \\
(0.005)\end{array}$ & & $\begin{array}{r}-0.005 \\
(0.013)\end{array}$ & & $\begin{array}{c}0.016 \\
(0.015)\end{array}$ \\
\hline Automatic placement & & & & & & $\begin{array}{r}-0.096 \\
(0.064)\end{array}$ & & $\begin{array}{r}-0.069 \\
(0.073)\end{array}$ \\
\hline "Big Five" orchestra & & $\begin{array}{r}-0.154 \\
(0.035)\end{array}$ & & $\begin{array}{r}-0.059 \\
(0.024)\end{array}$ & & $\begin{array}{c}0.006 \\
(0.081)\end{array}$ & & $\begin{array}{r}-0.059 \\
(0.084)\end{array}$ \\
\hline $\begin{array}{l}\text { Total number of auditioners in } \\
\text { round }(\div 100)\end{array}$ & & $\begin{array}{c}-0.003 \\
(0.081)\end{array}$ & & $\begin{array}{c}0.014 \\
(0.031)\end{array}$ & & $\begin{array}{c}-0.371 \\
(0.521)\end{array}$ & & $\begin{array}{r}-0.262 \\
(0.756)\end{array}$ \\
\hline $\begin{array}{l}\text { Proportion female at the audition } \\
\text { round }\end{array}$ & & $\begin{array}{c}0.118 \\
(0.139)\end{array}$ & & $\begin{array}{c}0.312 \\
(0.134)\end{array}$ & & $\begin{array}{c}0.104 \\
(0.218)\end{array}$ & & $\begin{array}{c}0.067 \\
(0.159)\end{array}$ \\
\hline Principal & & $\begin{array}{r}-0.079 \\
(0.037)\end{array}$ & & $\begin{array}{r}-0.078 \\
(0.019)\end{array}$ & & $\begin{array}{c}-0.082 \\
(0.066)\end{array}$ & & $\begin{array}{r}-0.185 \\
(0.076)\end{array}$ \\
\hline Substitute & & $\begin{array}{l}0.165 \\
(0.081)\end{array}$ & & $\begin{array}{c}0.123 \\
(0.093)\end{array}$ & & $\begin{array}{c}0.167 \\
(0.183)\end{array}$ & & $\begin{array}{r}0.079 \\
(0.217)\end{array}$ \\
\hline $\begin{array}{l}p \text {-value of } H_{0}: \text { Blind }+ \text { (Female } \\
\quad \times \text { Blind })=0\end{array}$ & 0.053 & 0.063 & 0.342 & 0.285 & 0.089 & 0.170 & 0.222 & 0.042 \\
\hline Year fixed effects? & No & Yes & No & Yes & No & Yes & No & Yes \\
\hline$R^{2}$ & 0.748 & 0.775 & 0.687 & 0.697 & 0.774 & 0.794 & 0.811 & 0.878 \\
\hline Number of observations & 5,395 & 5,395 & 6,239 & 6,239 & 1,360 & 1,360 & 1,127 & 1,127 \\
\hline
\end{tabular}

Notes: The unit of observation is a person-round. The dependent variable is 1 if the individual is advanced to the next round and 0 if not. Standard errors are in parentheses. All specifications include individual fixed effects, an interaction for the sex being missing and a blind audition round, a dummy indicating if years since last audition is missing, and [in columns (3)-(8)] whether an automatic placement is missing.

Source: Eight-orchestra audition sample. See text.

round and those that were not. In the evennumbered columns we include year and instrument fixed effects, as well as individual and audition covariates. The individual correlates are whether the musician had an automatic placement in a semifinal or final round, years since the last audition in the sample, and the number of previous auditions in which we observe the musician to have competed. We also control for the total number of musicians in the round, the proportion female among contestants, and whether the audition is for a principal or substitute position.

Because 42 percent of the individuals in our sample competed in more than one round in our data set (24 percent of the musicians competed in more than one audition) and 6 percent competed both with and without a screen for a particular type of round (e.g., semifinal), we are able to use an individual fixed-effects strategy to control for contestant "ability" that does not change with time. In all columns of Table 6 we include individual fixed effects, in which case the identification is from individuals who auditioned both with and without a screen. ${ }^{38}$ The

\footnotetext{
${ }^{38}$ There are 639 person-rounds comprised of individuals who auditioned at a preliminary round that was not followed by a semifinal round [columns (1) and (2) of Table 6], both with and without a screen; on average these individuals competed in 2.7 such preliminary rounds. There are 55 person-rounds comprised of individuals who auditioned at a preliminary round that was followed by a semifinal round [columns (3) and (4)], both with and without a screen; on average these individuals competed in 2.4 such preliminary rounds. There are 223 person-rounds comprised of individuals who auditioned at a semifinal [columns (5) and (6)],
} 
effect of the screen here, therefore, is identified from differing audition procedures both within and across orchestras. ${ }^{39}$ Note that we include a dummy variable for whether the orchestra is among the "Big Five," to control for the quality of the orchestra.

The coefficient of interest is the interaction between "Female" and "Blind." A positive coefficient would show that screened auditions enhance a woman's likelihood of advancement. Because screened auditions are more likely to take place in later years than auditions without screens, the interaction between "Female" and "Blind" might simply reflect the fact that female musicians get better over time. Note, however, that for this effect to bias the coefficient, female musicians would have to improve faster with time than male musicians. Nevertheless, we have also included (in the individual covariates) the number of previous auditions the musician attended in our sample, the number of years since the last audition in the sample, and whether the candidate was an automatic placement. The coefficient on "Blind" reveals whether blind auditions change the likelihood that all contestants are advanced.

As in the raw tabulations of Table 5, we find that the screen has a positive effect on the likelihood that a woman is advanced from the preliminary round (when there is no semifi-

both with and without a screen; on average these individuals participated in 2.8 semifinal rounds. Finally, there are 67 person-rounds comprised of individuals who auditioned at a final round [columns (7) and (8)], both with and without a screen; on average these individuals participated in 2.4 final rounds. It should be noted that the number of person-rounds off of which we are identified in Table 6 can also be found in Table 5, with one exception. There are 223 person-rounds comprised of individuals who auditioned at the semifinal, both with and without a screen, in Table 6 and only 221 in Table 5 because there are two individuals we could not sex. We include these individuals in the regressions in Table 6 and add a dummy variable indicating that the sex is missing.

${ }^{39}$ An analysis of variance (ANOVA) across the entire sample, that is pooling all rounds, indicates that 19 percent of the variation in the use of the screen is across orchestras. Looking by audition round reveals that 73 percent of the variation in preliminaries, 53 percent of the variation in semifinals, and 71 percent of the variation in finals is across orchestras. By contrast, in Table 7 (which includes a subset of the orchestras, see table notes), just 1 percent of the variation in the use of the screen is across orchestras. nal) and from the finals. ${ }^{40}$ The effects, moreover, are statistically significant in both cases. The effect in the semifinal round, however, remains strongly negative. ${ }^{41}$ In addition, the magnitudes of the effects in Table 6 are similar to those implied by the raw tabulations (Table 5). For preliminaries that are not preceded by a semifinal, the blind audition increases the likelihood that a woman will be selected by about 11 percentage points. For female musicians who made it to the final round, the individual fixed-effects regression result indicates that the screen increases the likelihood of their winning by about 33 percentage points. $^{42}$

Assessing Potential Biases.-A concern with the preceding fixed-effects analysis is that, as noted earlier, female musicians who are improving over time are those who switch from not-blind to blind auditions and that the growth rate of their "ability" is faster than that of men. We attempted to address this potential bias by including several individual time-varying co-

\footnotetext{
${ }^{40}$ An exception occurs when preliminaries are followed by semifinals. There are, however, only three preliminary rounds that are not blind when there is also a semifinal round (see Table 3 ). Thus the coefficients in columns (3) and (4) of Table 6 are identified using very few separate audition rounds. We also note that when we estimate fixedeffects logit models we obtain results similar to those in columns (1) and (2) in Table 6 (and in Table 7). Because of the small samples with the identifying requirements of the fixed-effects logit, standard errors for the estimates in columns (3)-(8) of Table 6 could not be computed. Further, for the results without individual fixed effects, logits and linear probability models give qualitatively similar results.

${ }^{41}$ This result on the semifinals is robust across time, instrument, position, and orchestra. One interpretation is that it represents a form of affirmative action by the audition committees. Committees may hesitate to advance women from the preliminary round if they are not confident of the candidate's ability. On the other hand, semifinals are typically held the same day as are preliminaries and give the audition committee a second chance to hear a candidate before the finals. Thus, audition committees may actively advance women to the final round only when they are reasonably confident that the female candidate is above some threshold level of quality. If juries actively seek to increase the presence of women in the final round, they can do so only when there is no screen.

${ }^{42}$ As noted earlier, an obvious explanation for the importance of the individual fixed effects in the estimation is that the screen altered the pool of female applicants; however, we have been unable to show this empirically.
} 
variates (in the even-numbered columns of Table 6). The inclusion of these individual covariates had little effect on the estimated effect of the screen.

A related concern is that those individuals who get hired at their first audition, and therefore do not contribute to the identification of the effect in the presence of individual fixed effects, are more able musicians than those who audition multiple times. (Alternatively, some individuals who audition and are not hired may get discouraged and not audition again and are therefore worse than those who audition multiple times.) Although this is a potential source of bias, it is important to remember that only a very small number of musicians win an audition in any given year, since there are just a handful of auditions (for a given instrument) among the major orchestras. Furthermore, many of the contestants in our sample did audition at least twice.

In addition, there are three pieces of empirical evidence that suggest this potential source of bias is not a major problem in our data. First, we control for the number of previous auditions in the even columns of Table 6 , and this control does not change the results significantly. Second, there is no significant difference in the proportion female among those who auditioned both with and without a screen and those who auditioned only once (or who auditioned under only one policy regime). Finally, the coefficient estimates generated when the sample is restricted to those who auditioned at least three times are not perceptibly different from those generated from the full sample or from the sample of individuals who auditioned both with and without a screen. (These results are presented in Table A4.)

A third potential bias is that, because the effect of the screen is partially identified from differing audition procedures across orchestras, the results in Table 6 may indicate that orchestras that use screens are less discriminatory against women than those that do not. Specifically, because we include individual fixed effects, a bias would arise if women who are improving faster than average are more likely to audition for orchestras that use screens and are more likely to be advanced because these orchestras are intrinsically less discriminatory. Our sample contains only one orchestra per audition round that changed policy. As a result, we cannot separate the estimation by audition round and include orchestra fixed effects. We can, however, pool the audition rounds for the three orchestras that changed audition policy during our sample frame and include both individual and orchestra fixed effects. ${ }^{43}$ These results are presented in Table 7.

In column (1) of Table 7 we include individual fixed effects, in which case the identification is from individuals who auditioned both with and without a screen. We add orchestra fixed effects in column (2) such that the identification now is from individuals who auditioned for a particular orchestra both before and after the orchestra began using a screen. ${ }^{44}$ Finally, in column (3) we exclude individual but keep orchestra fixed effects to illustrate the importance of individual fixed effects. Again, the coefficient on "Blind" shows whether all musicians are more likely to be advanced when the audition is blind. The interaction between whether the individual is female and whether the audition is blind indicates whether women receive an extra boost relative to men when the screen is used.

The coefficient of interest is positive in columns (1) and (2) but negative in column (3), similar to the difference between the tabulations in Tables 4 and 5. In addition, the estimated effect of the blind auditions on the success of women is similar to that in Table 6. The point is that individual fixedeffects estimation matters; orchestra fixed effects, however, do not matter. In all cases, blind auditions increase the probability of advancement for both men and women. More

\footnotetext{
${ }^{43}$ We do not include the type of audition round since we have only one orchestra that changed procedures for the preliminaries, one that changed for the semifinals, and one that changed for the finals (and for which there were musicians who auditioned for that orchestra and audition round with and without a screen). We have also estimated these regressions separately for each of these three orchestras. Although the point estimates are not statistically significant, the magnitudes are quite similar to those presented in Table 6 for the corresponding round of the audition.

${ }^{44}$ In this subsample, there are 1,776 person-rounds comprised of individuals who auditioned for a particular orchestra, both behind and without a screen; on average these 552 individuals competed in 3.2 audition rounds.
} 
Table 7-Linear Probability Estimates of the Likelihood of Being Advanced: With INDIVIDUAL AND ORCHESTRA FIXED EFFECTS

\begin{tabular}{lcccc}
\hline \hline & \multicolumn{2}{c}{$\begin{array}{c}\text { Include individual } \\
\text { fixed effects }\end{array}$} & & $\begin{array}{c}\text { Exclude individual } \\
\text { fixed effects }\end{array}$ \\
\cline { 2 - 3 } & $(1)$ & $(2)$ & & $(3)$ \\
\hline Blind & 0.404 & 0.399 & & 0.103 \\
Female $\times$ Blind & $(0.027)$ & $(0.027)$ & & $(0.018)$ \\
Female & 0.044 & 0.041 & & -0.069 \\
& $(0.039)$ & $(0.039)$ & & $(0.022)$ \\
$p$-value of $H_{0}:$ & & & -0.005 \\
$\quad$ Blind + Female $\times$ Blind) $=0$ & 0.000 & 0.000 & $(0.019)$ \\
Individual fixed effects? & & & 0.090 \\
Orchestra fixed effects? & Yes & Yes & No \\
Year fixed effects? & No & Yes & Yes \\
Other covariates? & Yes & Yes & Yes \\
$R^{2}$ & Yes & Yes & Yes \\
Number of observations & 0.615 & 0.615 & 0.048 \\
\hline & 8,159 & 8,159 & 8,159 \\
\hline
\end{tabular}

Notes: The unit of observation is a person-round. The dependent variable is 1 if the person is advanced to the next round and 0 if not. Standard errors are in parentheses. All specifications include an interaction for the sex being missing and a blind audition; "Other covariates" include automatic placement, years since last audition, number of auditions attended, size of the audition round, proportion female in audition round, whether a principal or substitute position, and a dummy indicating whether years since last audition is missing. These regressions include only the orchestras that changed their audition policy during our sample years and for which we observe individuals auditioning for the audition round both before and after the policy change. These regressions include 4,836 separate persons and are identified off of 1,776 person-rounds comprised of individuals who auditioned both before and after the policy change for a particular orchestra. Source: Eight-orchestra audition sample (three orchestras of which are used; see Notes). See text.

important, even though the effect is not statistically significant, the blind procedure has a positive effect on women's advancement. ${ }^{45}$

Finally, sex misclassification may also bias our estimates because, if the misclassification errors are uncorrelated with the equation error, the estimated effect of the screen will be attenuated (see, e.g., Richard Freeman, 1984). To address this potential problem, we use a lesssubjective assessment of the probability that the individual is male or female. A U.S. Bureau of the Census tabulation, based on the postenu-

\footnotetext{
${ }^{45}$ Although the results from these three orchestras may not generalize to the other five, it should be noted that the coefficient estimate in column (3) of Table 7 is similar to that derived from a similar regression on the entire sample. This result is not surprising because the primary reason we are able to include both individual and orchestra fixed effects for these three orchestras is because they have unusually good record keeping, which allows us to observe the results of many auditions rather than another reason that might be correlated with how meritocratic the orchestra is.
}

meration survey of the 1990 census, gives us the proportion female and male of the top 90 percent of all names. ${ }^{46}$

In Table 8 we estimate the same specifications given by columns (2), (4), (6), and (8) of Table 6 and column (2) of Table 7 using the census data in two ways. First, we simply replace our female covariate with the census probability. ${ }^{47}$ Note that we also use a census estimate of the percentage of the audition round that is female (slightly changing our sample size), and a census estimate of the percentage of our sample for which the sex is indeterminate. In addition, our interaction term is constructed using the census probabilities. Second, we use

\footnotetext{
46 These data can be downloaded from http://www.census. gov/ftp/pub/genealogy/names. A possible problem with the data is that names are generational; a male name in one generation may become female in another.

${ }^{47}$ We do not impute census probabilities for the individuals whose sex we know with certainty (see footnote 31 ).
} 
Table 8-Linear Probability Estimates of the Likelihood of Being Advanced: Addressing Sex Misclassification

\begin{tabular}{lcccc}
\hline \hline \multicolumn{2}{c}{ Part A: Preliminary rounds } \\
\cline { 2 - 5 } & \multicolumn{2}{c}{ Preliminaries } \\
\cline { 2 - 5 } & \multicolumn{2}{c}{ Without semifinals } & \multicolumn{2}{c}{ With semifinals } \\
\cline { 2 - 5 } & OLS & IV & OLS & IV \\
\hline Blind & -0.012 & 0.057 & -0.174 & 0.290 \\
& $(0.043)$ & $(0.045)$ & $(0.093)$ & $(0.241)$ \\
Female $\times$ Blind & 0.139 & 0.137 & 0.272 & $(0.251)$ \\
& $(0.066)$ & $(0.068)$ & Yes & Yes \\
Other covariates? & Yes & Yes & Yes & Yes \\
Individual fixed effects? & Yes & Yes & Yes & Yes \\
Year fixed effects? & Yes & & & $6,188)$ \\
$R^{2}$ & 0.771 & 5,395 & 6,546 & 6,239
\end{tabular}

Part B: Semifinal and final rounds, and with orchestra fixed effects

\begin{tabular}{|c|c|c|c|c|c|c|}
\hline & \multicolumn{2}{|c|}{ Semifinals } & \multicolumn{2}{|c|}{ Finals } & \multicolumn{2}{|c|}{$\begin{array}{c}\text { With orchestras fixed } \\
\text { effects }\end{array}$} \\
\hline & OLS & IV & OLS & IV & OLS & IV \\
\hline Blind & $\begin{array}{c}0.100 \\
(0.083)\end{array}$ & $\begin{array}{c}-0.197 \\
(0.700)\end{array}$ & $\begin{array}{c}-0.028 \\
(0.125)\end{array}$ & $\begin{array}{c}-0.025 \\
(0.141)\end{array}$ & $\begin{array}{c}0.010 \\
(0.028)\end{array}$ & $\begin{array}{c}0.061 \\
(0.033)\end{array}$ \\
\hline Female $\times$ Blind & $\begin{array}{c}-0.242 \\
(0.120)\end{array}$ & $\begin{array}{c}-0.193 \\
(0.429)\end{array}$ & $\begin{array}{c}0.160 \\
(0.171)\end{array}$ & $\begin{array}{c}0.324 \\
(0.181)\end{array}$ & $\begin{array}{c}0.069 \\
(0.035)\end{array}$ & $\begin{array}{c}0.052 \\
(0.036)\end{array}$ \\
\hline Other covariates & Yes & Yes & Yes & Yes & Yes & Yes \\
\hline Individual fixed effects? & Yes & Yes & Yes & Yes & Yes & Yes \\
\hline Year fixed effects? & Yes & Yes & Yes & Yes & Yes & Yes \\
\hline$R^{2}$ & 0.776 & & 0.848 & & 0.654 & \\
\hline Number of observations & 1,600 & 1,360 & 1,509 & 1,127 & 8,882 & 8,159 \\
\hline
\end{tabular}

Notes: The unit of observation is a person-round. The dependent variable is 1 if the individual is advanced to the next round and 0 if not. Standard errors are in parentheses. The instruments are the census probability that the individual is female, a dummy for whether the person has been sexed with certainty, and proportion female calculated using the census data and an interaction between whether the census data are missing and a screen has been used. The "OLS" columns use these as regressors. All specifications include an interaction for the sex being missing and a blind audition; "Other covariates" include automatic placement, years since last audition, number of auditions attended, whether a "Big Five" orchestra, size of the audition round, proportion female at the audition round, whether a principal or substitute position, and a dummy indicating whether years since last audition and automatic audition are missing. These are the same specifications as in columns (2), (4), (6), and (8) of Table 6 and column (2) of Table 7. The sample sizes change because in the even-numbered columns we simply replace our female covariate with the census probability and also use a census estimate of the percentage of the audition round that is female, which changes the sample size slightly.

Source: Eight-orchestra audition sample. See text.

the census probability as an instrument for our estimate (and for the percentage of the audition that is female, the percentage missing sex, and the interaction between female and whether the audition is blind).

The results are quite robust across these different methods for addressing potential measurement error. More important, the coefficients and their standard errors are generally similar in magnitude to those in Tables 6 and 7 . With the exception of the semifinal round, the screen appears to have increased the likelihood that a woman would be advanced. ${ }^{48}$

${ }^{48}$ Another potential bias is from the short panel, which may affect the consistency of the estimates (Hsiao, 1986). We address the extent of this short panel problem in two ways. We first restrict our sample to those whom we observe auditioning at least three times (for the same round). Second, we restrict the estimation to those who auditioned at least once in a blind round and at least once in a not-blind round (those off of whom we are identified). The results do not change markedly from those in Table 6 , showing that the short panel may not be a problem. See Table A4. 
Table 9-Linear Probability Estimates of the EfFect of Blind Auditions on the LiKelihood of Being HiRed with Individual FiXed EFFECTS

\begin{tabular}{|c|c|c|c|c|c|c|}
\hline & \multicolumn{2}{|c|}{ Without semifinals } & \multicolumn{2}{|c|}{ With semifinals } & \multicolumn{2}{|c|}{ All } \\
\hline & (1) & $(2)$ & (3) & (4) & (5) & (6) \\
\hline \multirow[t]{2}{*}{ Completely blind audition } & -0.024 & 0.047 & 0.001 & 0.006 & 0.001 & 0.005 \\
\hline & $(0.028)$ & $(0.041)$ & $(0.009)$ & $(0.011)$ & $(0.008)$ & $(0.009)$ \\
\hline \multirow{2}{*}{ Completely blind audition $\times$ female } & 0.051 & 0.036 & 0.001 & -0.004 & 0.011 & 0.006 \\
\hline & $(0.046)$ & $(0.048)$ & $(0.016)$ & (0.016) & $(0.013)$ & (0.013) \\
\hline Year effects? & No & Yes & No & Yes & No & Yes \\
\hline Other covariates? & No & Yes & No & Yes & No & Yes \\
\hline$R^{2}$ & 0.855 & 0.868 & 0.692 & 0.707 & 0.678 & 0.691 \\
\hline Number of observations & 4,108 & 4,108 & 5,883 & 5,883 & 9,991 & 9,991 \\
\hline
\end{tabular}

Notes: The unit of observation is a person-round. The dependent variable is 1 if the individual is advanced (or hired) from the final round and 0 if not. Standard errors are in parentheses. All specifications include individual fixed effects, whether the sex is missing, and an interaction for sex being missing and a completely blind audition. "Other covariates" are the size of the audition, the proportion female at the audition, the number of individuals advanced (hired), whether a "Big Five" orchestra, the number of previous auditions, and whether the individual had an automatic semifinal or final.

Source: Eight-orchestra audition sample. See text.

\section{The Effect of the Screen on the Hiring of Women}

Using the Audition Sample.-Our analysis, thus far, has concerned the rounds of the audition process and the degree to which the screen enhances the likelihood of a woman's advancing from one round to the next. We turn now to the effect of the screen on the actual hire and estimate the likelihood an individual is hired out of the initial audition pool. ${ }^{49}$ Whereas the use of the screen for each audition round was, more or less, an unambiguous concept, that for the entire process is not and we must define a blind audition. The definition we have chosen is that a blind audition contains all rounds that use the screen. In using this definition, we compare auditions that are completely blind with those that do not use the screen at all or use it for the early rounds only. We divide the sample into auditions that have a semifinal round and those that do not, because the previous analysis suggested they might differ.

The impact of completely blind auditions on the likelihood of a woman's being hired is given in Table 9, for which all results include individ-

\footnotetext{
${ }^{49}$ There are four auditions in which the committee could not choose between two players and therefore asked each to play with the orchestra. We consider both to be winners. The results are not sensitive to this classification. For this analysis we exclude auditions with no women, all women, or no winner; these exclusions do not change the results.
}

ual fixed effects. ${ }^{50}$ The impact of the screen is positive and large in magnitude, but only when there is no semifinal round. Women are about 5 percentage points more likely to be hired than are men in a completely blind audition, although the effect is not statistically significant. The effect is nil, however, when there is a semifinal round, perhaps as a result of the unusual effects of the semifinal round. The impact for all rounds [columns (5) and (6)] is about 1 percentage point, although the standard errors are large and thus the effect is not statistically significant. Given that the probability of winning an audition is less than 3 percent, we would need more data than we currently have to estimate a statistically significant effect, and even a 1-percentage-point increase is large, as we later demonstrate.

\footnotetext{
${ }^{50}$ In Table 9 we are identified off of individuals who competed in auditions that were completely blind and those that were not completely blind (that is, any one round could not be blind). The unit of observation is the person-round and there are 92 fulfilling this criterion for auditions without a semifinal [columns (1) and (2)]; on average these persons competed in 3.6 auditions in this sample. There are 625 person-rounds fulfilling this criterion that included a semifinal [columns (3) and (4)] and on average these persons competed in 3.5 auditions in this sample. Finally, there are 911 person-rounds fulfilling this criterion across all audition [columns (5) and (6)] and on average these persons competed in 3.5 auditions in this sample. The sample off of which we are identified is larger for all auditions than for the sum of the other two because some individuals auditioned both with and without a semifinal round.
} 
Table 10-Probit Estimates of the Effect of Blind Auditions on the SeX of New MEMBERS: 1970 TO 1996

\begin{tabular}{|c|c|c|}
\hline & $\begin{array}{l}\text { Any blind } \\
\text { auditions }\end{array}$ & $\begin{array}{l}\text { Only blind preliminaries } \\
\text { and/or semifinals vs. } \\
\text { completely blind } \\
\text { auditions }\end{array}$ \\
\hline & (1) & (2) \\
\hline Any blind auditions & $\begin{array}{c}0.238 \\
(0.183) \\
{[0.075]}\end{array}$ & \\
\hline $\begin{array}{l}\text { Only blind preliminaries and/or } \\
\text { semifinals }\end{array}$ & & $\begin{array}{c}0.232 \\
(0.184) \\
{[0.074]}\end{array}$ \\
\hline Completely blind auditions & & $\begin{array}{c}0.361 \\
(0.438) \\
{[0.127]}\end{array}$ \\
\hline \multicolumn{3}{|l|}{ Section: } \\
\hline Woodwinds & $\begin{array}{c}-0.187 \\
(0.114) \\
{[-0.058]}\end{array}$ & $\begin{array}{r}-0.188 \\
(0.114) \\
{[-0.058]}\end{array}$ \\
\hline Brass & $\begin{array}{c}-1.239 \\
(0.157) \\
{[-0.284]}\end{array}$ & $\begin{array}{r}-1.237 \\
(0.157) \\
{[-0.284]}\end{array}$ \\
\hline Percussion & $\begin{array}{c}-1.162 \\
(0.305) \\
{[-0.235]}\end{array}$ & $\begin{array}{r}-1.164 \\
(0.305) \\
{[-0.235]}\end{array}$ \\
\hline $\begin{array}{l}p \text {-value of test: only blind preliminaries } \\
\text { and/or semifinals = completely blind } \\
\text { pseudo } R^{2}\end{array}$ & 0.106 & 0.756 \\
\hline Number of observations & 1,128 & 1,128 \\
\hline
\end{tabular}

Notes: The dependent variable is 1 if the individual is female and 0 if male. Standard errors are in parentheses. All specifications include orchestra fixed effects and orchestra-specific time trends. Changes in probabilities are in brackets; see text for an explanation of how they are calculated. New members are those who enter the orchestra for the first time. Returning members are not considered new. The omitted section is strings.

Source: Eleven-orchestra roster sample. See text.

Using the Roster Data.-The roster data afford us another way to evaluate the effect of the screen on the sex composition of orchestras. Using the rosters we know the sex of new hires each year for 11 orchestras, and we also have information (see Table 1) on the year the screen was adopted by each orchestra. We treat the orchestra position as the unit of observation and ask whether the screen affects the sex of the individual who fills the position. We model the likelihood that a female is hired in a particular year as a function of whether the orchestra's audition procedure involved a screen, again relying on the variation over time within a particular orchestra. Thus, in all specifications, we include orchestra fixed effects and an orchestraspecific time trend.

The roster data extend further back in time than do the audition data and could conceivably begin with the orchestra's founding, although there is no obvious reason to include many years when none used the screen. We report, in Table 10, the effects of the screen on the hiring of women from 1970 to 1996 using a probit model. The screen is first defined to include any blind auditions [column (1)]. In column (2) we estimate separate effects for orchestras using blind preliminary (and semifinal) rounds but not blind finals and those with completely blind auditions.

To interpret the probit coefficient, we first predict a base probability, under the assumption that each orchestra does not use a screen. We then predict a new probability assuming the orchestra uses a screen. The mean difference in the probabilities is given in brackets. 
The coefficient on blind in column (1) is positive, although not significant at any usual level of confidence. The estimates in column (2) are positive and equally large in magnitude to those in column (1). Further, these estimates show that the existence of any blind round makes a difference and that a completely blind process has a somewhat larger effect (albeit with a large standard error). ${ }^{51}$ According to the point estimates in column (1) of Table 10, blind auditions increase the likelihood a female will be hired by 7.5 percentage points. The magnitude of the effect must be judged relative to the overall average and, for the period under consideration, it was about 30 percent. ${ }^{52}$ Thus blind auditions increased the likelihood a female would be hired by 25 percent.

Making Further Sense of the Results on Hiring.-The audition sample results suggest that blind auditions increase the probability of eventual success for a female candidate by 5 percentage points, but only if there is no semifinal round. The average effect for both types of auditions is closer to 1 percentage point (with a large standard error). The following example, using assumed values based on the actual data, demonstrates that an increase of about 2 percentage points in the probability of a woman's success out of an audition can explain the entire change in female hires, allowing the share of candidates who are female to increase from 0.2 to 0.3 . Thus an increase of 1 percentage pointour point estimate-can account for a substantial share.

Consider two regimes: one without the screen (not blind) and another with the screen (blind). In the not-blind regime, assume that 20 percent of the candidates are female and that in the blind regime 30 percent are female. ${ }^{53}$ We know that

\footnotetext{
${ }^{51}$ We have also attempted to interact the effect of blind auditions with section dummies. We find that the main effect of blind auditions is almost identical to that for the string section, which is not surprising given that the strings comprise 65 percent of the observations. In addition, fewer than 4 percent of the musicians hired into the percussion and brass sections are female.

52 See Table A2.

${ }^{53}$ The fraction female in the not-blind regime (taking it to be the period before 1970) is 0.187 in our data (see Table 3 ). In the blind regime it was between 0.35 and 0.4 . We have chosen the more conservative 0.3 in the example
}

in the era (say, before 1970) when few orchestras used the screen for the preliminary round (see Table 1), 10 percent (that is, 0.0996) of new hires were women. Also assume that 30 candidates enter each audition, independent of audition regime, and that one musician is hired out of each audition. Using these assumptions, taken from the actual data, the success rate for the typical female audition candidate in the notblind regime will be 0.0166 and that for the typical male will be 0.0375 . If in the blind regime, however, the percentage of new hires who are female increases to 35 percent (its approximate figure for the past 10 years), the success rate for a female audition candidate must have increased to 0.0389 (and that for a male must have decreased to 0.0310). That is, for consistency with the data on percent female, the success rate for female candidates would have had to increase by about 2.2 percentage points, moving from the not-blind to the blind regime. Our point estimate is that about half of that increase- 1 percentage point - was the result of the effect of the screened audition process.

Using the example we just offered, the increase in the probability of a woman's being hired out of an audition accounts for 66 percent of the total increase in the fraction female among new hires. Half of the 66 percent comes from the switch to blind auditions. ${ }^{54}$ The other half could have resulted, for example, from a

because we want to use a number that is independent of the switch to using the screen. That is, we would like to use a fraction female that is solely the result of increases in female participation in general but independent of changes in audition procedures.

54 The proportion female among new hires is $(n \cdot \lambda \cdot \alpha)$, where $n=$ the number of audition candidates (in this example $n=30) ; \lambda=$ the success rate of the average female candidate, which may be enhanced by the screen (in this example $\lambda$ increases from 0.0166 to 0.0389 or by 2.2 percentage points, about half of which is due to the screen, based on our estimates); and $\alpha=$ the fraction female among candidates (assumed here to increase from 20 to 30 percent independent of $\lambda$ ). The percentage of the total change accounted for by the change in $\lambda$ is given by $(n \cdot \alpha \cdot$ $\Delta \lambda) / \Delta(n \cdot \lambda \cdot \alpha)$ or on average by $[(30 \cdot 0.25 \cdot 0.022) /$ $(0.35-0.0996)=66$ percent. (The 0.25 figure is the average of that in the treatment period and that previously.) Since half is accounted for by the screen, about 33 percent of the increase in the proportion female among new hires comes from the blind audition process. 
greater acceptance of female musicians by music directors. The remainder ( 34 percent) of the increase in the fraction female among new hires is accounted for by the increased percentage female among audition candidates. That portion comes primarily from the increase in the fraction female among music school graduates.

The point estimates from the roster data also suggest that a substantial portion of the increase in female hires across the two regimes, notblind and blind, can be explained by the change in audition procedures. In the not-blind regime about 10 percent of all hires are female but in the blind regime about 35 percent are, a difference of 25 percentage points. The estimates in column (1) of Table 10 show that the switch to the blind regime increases the likelihood a woman will be hired by 7.5 percentage points-30 percent of the total change-although we emphasize that the coefficient is imprecisely estimated.

One may wonder why there was disparate treatment of female musicians before the screen was used. A great orchestra is not simply a collection of the finest musicians. It is, rather, a group of great musicians who play magnificently as an ensemble. Substantial amounts of specific human capital are acquired on the job and tenure differences by sex, therefore, could influence hiring decisions. ${ }^{55}$ Leaves of absence are ordinarily allowed for medical (including maternity) and professional reasons. We find, using the roster sample from 1960 to 1996 , that the average female musician took 0.067 leaves per year, whereas the average male musician took 0.061 , a difference that is not statistically significant, and that their length of leave was trivially different. Tenure differences were also small and some specifications show that women accumulated more years with an orchestra, given their starting year and orchestra. ${ }^{56}$ Turn-

\footnotetext{
${ }^{55}$ Musicians of the Vienna Philharmonic made this argument in a radio broadcast by the West German State Radio in February 1996 [translation provided by William Osborne]. See also New York Times (1996) in which a player for the Vienna Philharmonic argued that female musicians would cost the orchestra considerably more because substitutes would have to be hired if they became pregnant.

${ }^{56}$ The general specification is number of actual years with an orchestra as a function of the starting year, section dummies, and a female dummy, for the period since 1959. The
}

over and leaves of absence do not appear to differ by sex and thus should not have rationally influenced hiring decisions.

\section{Conclusion}

The audition procedures of the great U.S. symphony orchestras began to change sometime in the 1970 's. The changes included increasing the number of candidates at auditions - a democratization of the process - and using a physical screen during the audition to conceal the candidate's identity and ensure impartiality. We analyze what difference blind auditions have meant for female musicians.

We have collected, from orchestral management files and archives, a sample of auditions for eight major orchestras. These records contain the names of all candidates and identify those advanced to the next round, including the ultimate winner of the competition. The data provide a unique means of testing whether discrimination existed in the various rounds of a hiring process and even allow the linkage of individuals across auditions. A strong presumption exists that discrimination has limited the employment of female musicians, especially by the great symphony orchestras. Not only were their numbers extremely low until the 1970's, but many music directors, ultimately in charge of hiring new musicians, publicly disclosed their belief that female players had lower musical talent.

The question is whether hard evidence can support an impact of discrimination on hiring. Our analysis of the audition and roster data indicates that it can, although we mention various caveats before we summarize the reasons. Even though our sample size is large, we identify the coefficients of interest from a much smaller sample. Some of our coefficients of interest, therefore, do not pass standard tests of statistical significance and there is, in addition, one persistent result that goes in the opposite direction. The weight of the evidence, however, is what we find most persuasive and what we

coefficient on the female dummy is -0.299 with a large standard error (the mean of tenure is 11.7 years). With the addition of orchestra fixed effects, the coefficient on the female dummy is +0.062 , again with a large standard error. The difference in tenure by sex, therefore, is extremely small. 
have emphasized. The point estimates, moreover, are almost all economically significant.

Using the audition data, we find that the screen increases-by 50 percent-the probability that a woman will be advanced from certain preliminary rounds and increases by severalfold the likelihood that a woman will be selected in the final round. By the use of the roster data, the switch to blind auditions can explain 30 percent of the increase in the proportion female among new hires and possibly 25 percent of the increase in the percentage female in the orchestras from 1970 to $1996 .{ }^{57}$ As in research in economics and other fields on double-blind refereeing (see, e.g.,

\footnotetext{
${ }^{57}$ The point estimate for the increased likelihood a woman would be a new hire, as a result of the adoption of blind auditions, is 7.5 percentage points using the roster data (see Table 10). Because the percentage female among new hires increased from 10 to 35 percent from before 1970 to the 1990 's, our estimate implies that 30 percent of the 25 percentage-point increase can be explained by the adoption
}

Blank, 1991), the impact of a blind procedure is toward impartiality and the costs to the journal (here to the orchestra) are relatively small. We conclude that the adoption of the screen and blind auditions served to help female musicians in their quest for orchestral positions.

of the screen. How this increase affected the percentage female in the orchestra depends on the sex composition of the orchestra, retirement (or turnover), and the time frame. We assume a 25-year time frame (from 1970 to 1995) and two retirements (thus two hires) per year. An increase in the percentage female among new hires from 10 percent (its level pre-1970) to 17.5 percent $(10+7.5 \%)$ implies that in 25 years, 13.75 women (out of 100) will be in the orchestra, or an increase of 3.75. The actual increase was 15 women, meaning 25 percent of the increase can be explained by the adoption of the screen. We assume in this example that the age distribution of the 100 players in 1970 is uniform between ages 25 and 74, that all hires occur at age 25, and that men and women are drawn from the same age distribution.

\section{APPENDIX}

Table A1-Sample Descriptive Statistics, Audition Data

\begin{tabular}{|c|c|c|c|c|c|c|c|c|}
\hline & \multicolumn{4}{|c|}{ Preliminaries } & & & & \\
\hline & \multicolumn{2}{|c|}{ Without semifinals } & \multicolumn{2}{|c|}{ With semifinals } & \multicolumn{2}{|c|}{ Semifinals } & \multicolumn{2}{|c|}{ Finals } \\
\hline & Mean & $\begin{array}{r}\text { Standard } \\
\text { deviation }\end{array}$ & Mean & $\begin{array}{l}\text { Standard } \\
\text { deviation }\end{array}$ & Mean & $\begin{array}{l}\text { Standard } \\
\text { deviation }\end{array}$ & Mean & $\begin{array}{l}\text { Standard } \\
\text { deviation }\end{array}$ \\
\hline Advanced & 0.184 & 0.387 & 0.185 & 0.388 & 0.349 & 0.477 & 0.200 & 0.400 \\
\hline Blind & 0.793 & 0.405 & 0.976 & 0.152 & 0.808 & 0.394 & 0.122 & 0.328 \\
\hline Female & 0.376 & 0.485 & 0.374 & 0.484 & 0.410 & 0.492 & 0.411 & 0.492 \\
\hline Female $\times$ Blind & 0.305 & 0.461 & 0.362 & 0.481 & 0.325 & 0.469 & 0.056 & 0.230 \\
\hline Missing female & 0.002 & 0.047 & 0.002 & 0.047 & 0.004 & 0.066 & 0 & 0 \\
\hline Missing female $\times$ Blind & 0.002 & 0.043 & 0.002 & 0.047 & 0.004 & 0.061 & 0 & 0 \\
\hline Years since last audition & 2.480 & 1.661 & 2.621 & 2.209 & 2.432 & 2.393 & 2.272 & 1.895 \\
\hline $\begin{array}{l}\text { Years since last audition, } \\
\text { missing }\end{array}$ & 0.663 & 0.473 & 0.505 & 0.500 & 0.386 & 0.487 & 0.505 & 0.500 \\
\hline Automatic placement & - & - & - & - & 0.267 & 0.443 & 0.137 & 0.345 \\
\hline $\begin{array}{l}\text { Number of auditions } \\
\text { attended }\end{array}$ & 1.611 & 1.137 & 2.147 & 1.717 & 2.490 & 1.886 & 2.051 & 1.513 \\
\hline "Big Five" orchestra & 0.607 & 0.488 & 0.323 & 0.467 & 0.213 & 0.409 & 0.391 & 0.488 \\
\hline $\begin{array}{l}\text { Total number of } \\
\text { auditioners }\end{array}$ & 44.348 & 22.202 & 64.279 & 35.914 & 15.054 & 7.187 & 8.622 & 4.445 \\
\hline Proportion female at round & 0.375 & 0.206 & 0.373 & 0.239 & 0.407 & 0.211 & 0.411 & 0.213 \\
\hline Principal & 0.192 & 0.394 & 0.368 & 0.482 & 0.353 & 0.478 & 0.278 & 0.448 \\
\hline Substitute & 0.025 & 0.157 & 0.005 & 0.071 & 0.010 & 0.101 & 0.021 & 0.141 \\
\hline $\begin{array}{l}\text { Number of observations } \\
\text { (person-rounds) }\end{array}$ & \multicolumn{2}{|c|}{5,395} & \multicolumn{2}{|c|}{6,239} & \multicolumn{2}{|c|}{1,360} & \multicolumn{2}{|c|}{1,127} \\
\hline
\end{tabular}

Source: Eight-orchestra audition sample. See text. 
Table A2-Sample Descriptive Statistics, Roster Data: 1970 to 1996

\begin{tabular}{|c|c|c|}
\hline & Mean & Standard deviation \\
\hline Proportion female among new hires & 0.293 & 0.455 \\
\hline$(\text { Proportion female })_{t-1}$ & 0.179 & 0.081 \\
\hline Only blind preliminary auditions & 0.572 & 0.495 \\
\hline All auditions blind & 0.104 & 0.305 \\
\hline \multicolumn{3}{|l|}{ Section: } \\
\hline Strings & 0.642 & 0.480 \\
\hline Woodwinds & 0.158 & 0.365 \\
\hline Brass & 0.165 & 0.371 \\
\hline Percussion & 0.035 & 0.185 \\
\hline Number of observations & \multicolumn{2}{|c|}{1,128} \\
\hline
\end{tabular}

Note: Means are musician weighted, not audition weighted.

Source: Eleven-orchestra roster sample. See text.

Table A3-Linear Probability Estimates of the Likelihood of Being Advanced: by Round

\begin{tabular}{|c|c|c|c|c|c|c|c|c|}
\hline & \multicolumn{4}{|c|}{ Preliminaries } & & & & \\
\hline & \multicolumn{2}{|c|}{$\begin{array}{l}\text { Without } \\
\text { semifinals }\end{array}$} & \multicolumn{2}{|c|}{$\begin{array}{c}\text { With } \\
\text { semifinals }\end{array}$} & \multicolumn{2}{|c|}{ Semifinals } & \multicolumn{2}{|c|}{ Finals } \\
\hline & (1) & (2) & (3) & (4) & (5) & (6) & (7) & (8) \\
\hline Female & $\begin{array}{c}0.007 \\
(0.025)\end{array}$ & $\begin{array}{c}0.011 \\
(0.025)\end{array}$ & $\begin{array}{r}-0.054 \\
(0.069)\end{array}$ & $\begin{array}{r}-0.085 \\
(0.069)\end{array}$ & $\begin{array}{c}0.103 \\
(0.061)\end{array}$ & $\begin{array}{c}0.099 \\
(0.061)\end{array}$ & $\begin{array}{c}0.002 \\
(0.028)\end{array}$ & $\begin{array}{l}0.0004 \\
(0.028)\end{array}$ \\
\hline Female $\times$ Blind & $\begin{array}{c}-0.062 \\
(0.028)\end{array}$ & $\begin{array}{c}-0.067 \\
(0.028)\end{array}$ & $\begin{array}{c}0.005 \\
(0.070)\end{array}$ & $\begin{array}{c}0.037 \\
(0.070)\end{array}$ & $\begin{array}{c}-0.142 \\
(0.066)\end{array}$ & $\begin{array}{c}-0.137 \\
(0.067)\end{array}$ & $\begin{array}{c}-0.091 \\
(0.075)\end{array}$ & $\begin{array}{c}-0.078 \\
(0.075)\end{array}$ \\
\hline Blind audition & $\begin{array}{c}0.015 \\
(0.022)\end{array}$ & $\begin{array}{c}0.040 \\
(0.030)\end{array}$ & $\begin{array}{c}0.024 \\
(0.057)\end{array}$ & $\begin{array}{c}0.027 \\
(0.062)\end{array}$ & $\begin{array}{c}0.053 \\
(0.049)\end{array}$ & $\begin{array}{c}0.115 \\
(0.078)\end{array}$ & $\begin{array}{c}0.058 \\
(0.058)\end{array}$ & $\begin{array}{c}0.123 \\
(0.089)\end{array}$ \\
\hline $\begin{array}{l}p \text {-value of } H_{0}: \\
\text { Female }+(\text { Female } \times \\
\quad \text { Blind })=0\end{array}$ & 0.000 & 0.000 & 0.000 & 0.000 & 0.210 & 0.222 & 0.207 & 0.271 \\
\hline Other covariates? & Yes & Yes & Yes & Yes & Yes & Yes & Yes & Yes \\
\hline $\begin{array}{l}\text { Instrument fixed } \\
\text { effects? }\end{array}$ & Yes & Yes & Yes & Yes & Yes & Yes & Yes & Yes \\
\hline Year fixed effects? & Yes & Yes & Yes & Yes & Yes & Yes & Yes & Yes \\
\hline Orchestra fixed effects? & No & Yes & No & Yes & No & Yes & No & Yes \\
\hline$R^{2}$ & 0.062 & 0.070 & 0.033 & 0.045 & 0.074 & 0.081 & 0.064 & 0.068 \\
\hline $\begin{array}{l}\text { Number of observations } \\
\text { (person-rounds) }\end{array}$ & 5,395 & 5,395 & 6,239 & 6,239 & 1,360 & 1,360 & 1,127 & 1,127 \\
\hline
\end{tabular}

Notes: The dependent variable is 1 if the individual is advanced to the next round and 0 if not. Standard errors are in parentheses. All specifications include dummies indicating whether the sex is missing, and an interaction for the sex being missing and a blind audition. "Other covariates" include automatic round, number of auditions attended, whether a "Big Five" orchestra, size of round, proportion female at the round, and whether a principal (including assistant and associate principal) or substitute position; except in columns (2), (4), (6), and (8) for which "Other covariates" include only automatic placement and number of auditions attended. These results are comparable to those in Table 6 but without individual fixed effects.

Source: Eight-orchestra audition sample. See text. 
Table A4-Linear Probability Estimates of the Likelihood of Being Advanced: Assessing Short-Panel Bias

\begin{tabular}{|c|c|c|c|c|c|c|}
\hline & \multicolumn{6}{|c|}{ Part A: Preliminary rounds } \\
\hline & \multicolumn{6}{|c|}{ Preliminaries } \\
\hline & \multicolumn{3}{|c|}{ Without semifinals } & \multicolumn{3}{|c|}{ With semifinals } \\
\hline & \multicolumn{2}{|c|}{$\mathrm{I}^{\mathrm{a}}$} & $\mathrm{II}^{\mathrm{b}}$ & \multicolumn{2}{|c|}{$\mathrm{I}^{\mathrm{a}}$} & $\mathrm{II}^{\mathrm{b}}$ \\
\hline Blind & \multicolumn{2}{|c|}{$\begin{array}{r}-0.024 \\
(0.066)\end{array}$} & $\begin{array}{r}-0.042 \\
(0.063)\end{array}$ & \multicolumn{2}{|c|}{$\begin{array}{r}-0.047 \\
(0.383)\end{array}$} & $\begin{array}{r}-0.095 \\
(0.744)\end{array}$ \\
\hline Female $\times$ Blind & \multicolumn{2}{|c|}{$\begin{array}{l}0.126 \\
(0.095)\end{array}$} & $\begin{array}{c}0.095 \\
(0.071)\end{array}$ & \multicolumn{2}{|c|}{-0.035} & $\begin{array}{c}0.041 \\
(0.275)\end{array}$ \\
\hline $\begin{array}{l}p \text {-value of } H_{0} \text { : } \\
\quad \text { Blind }+(\text { Female } \times \text { Blind })=0\end{array}$ & \multicolumn{2}{|c|}{0.233} & 0.502 & \multicolumn{2}{|c|}{0.807} & 0.943 \\
\hline Other covariates? & \multicolumn{2}{|c|}{ Yes } & Yes & \multicolumn{2}{|c|}{ Yes } & Yes \\
\hline Individual fixed effects? & \multicolumn{2}{|c|}{ Yes } & Yes & \multicolumn{2}{|c|}{ Yes } & Yes \\
\hline Year fixed effects? & \multicolumn{2}{|c|}{ Yes } & Yes & \multicolumn{2}{|c|}{ Yes } & Yes \\
\hline$R^{2}$ & \multicolumn{2}{|c|}{0.491} & 0.537 & \multicolumn{2}{|c|}{0.423} & 0.732 \\
\hline Number of observations (person-rounds) & \multicolumn{2}{|c|}{1,025} & 639 & \multicolumn{2}{|c|}{1,928} & 55 \\
\hline & \multicolumn{6}{|c|}{ Part B: Semifinals and finals, and with orchestra fixed effects } \\
\hline & \multicolumn{2}{|c|}{ Semifinals } & \multicolumn{2}{|c|}{ Finals } & \multicolumn{2}{|c|}{$\begin{array}{l}\text { With orchestras } \\
\text { fixed effects }\end{array}$} \\
\hline & $\mathrm{I}^{\mathrm{a}}$ & $\mathrm{II}^{\mathrm{b}}$ & $\mathrm{I}^{\mathrm{a}}$ & $\mathrm{II}^{\mathrm{b}}$ & $\mathrm{I}^{\mathrm{a}}$ & $\mathrm{II}^{\mathrm{b}}$ \\
\hline Blind & $\begin{array}{c}0.060 \\
(0.133)\end{array}$ & $\begin{array}{c}0.169 \\
(0.109)\end{array}$ & $\begin{array}{c}0.123 \\
(0.356)\end{array}$ & $\begin{array}{r}-0.140 \\
(0.449)\end{array}$ & $\begin{array}{c}0.084 \\
(0.047)\end{array}$ & $\begin{array}{c}0.352 \\
(0.056)\end{array}$ \\
\hline Female $\times$ Blind & $\begin{array}{r}-0.179 \\
(0.195)\end{array}$ & $\begin{array}{r}-0.284 \\
(0.142)\end{array}$ & $\begin{array}{c}0.157 \\
(0.408)\end{array}$ & $\begin{array}{c}0.403 \\
(0.415)\end{array}$ & $\begin{array}{c}0.042 \\
(0.051)\end{array}$ & $\begin{array}{c}0.021 \\
(0.041)\end{array}$ \\
\hline $\begin{array}{l}p \text {-value of } H_{0}: \\
\quad \text { Blind }+(\text { Female } \times \text { Blind })=0\end{array}$ & 0.438 & 0.298 & 0.212 & 0.587 & 0.011 & 0.000 \\
\hline Other covariates? & Yes & Yes & Yes & Yes & Yes & Yes \\
\hline Individual fixed effects? & Yes & Yes & Yes & Yes & Yes & Yes \\
\hline Year fixed effects? & Yes & Yes & Yes & Yes & Yes & Yes \\
\hline$R^{2}$ & 0.438 & 0.593 & 0.721 & 0.728 & 0.506 & 0.603 \\
\hline Number of observations (person-rounds) & 269 & 223 & 127 & 67 & 2,321 & 1,776 \\
\hline
\end{tabular}

Notes: The dependent variable is 1 if the individual is advanced to the next round and 0 if not. Standard errors are in parentheses. These are the same specifications as in columns (2), (4), (6), and (8) of Table 6 and column (2) of Table 7. Source: Eight-orchestra audition sample. See text.

${ }^{\text {a }}$ Includes those who auditioned at least three times (for the relevant round).

${ }^{\mathrm{b}}$ Includes those who auditioned at least once in a blind audition and at least once in a not-blind audition (for the relevant round).

\section{REFERENCES}

Allmendinger, Jutta; Hackman, J. Richard and Lehman, Erin V. "Life and Work in Symphony Orchestras." Music Quarterly, Summer 1996, 80(2), pp. 194-219.

Arrow, Kenneth. "The Theory of Discrimination," in Orley Ashenfelter and Albert Rees, eds., Discrimination in labor markets. Princeton, NJ: Princeton University Press, 1973, pp. 3-33.

Ayres, Ian and Waldfogel, Joel. "A Market Test for Race Discrimination in Bail Setting." Stanford Law Review, May 1994, 46(5), pp. 987-1047.
Becker, Gary. The economics of discrimination, 2nd Ed. Chicago: University of Chicago Press, 1971 [orig. pub. 1957].

Blank, Rebecca. "The Effects of Double-Blind versus Single-Blind Refereeing: Experimental Evidence from the American Economic Review." American Economic Review, December 1991, 81(5), pp. 104167.

Economist, The. "American Orchestras: All Ears." November 30, 1996.

Ellefson, Connie Lockhard. The melting pot book of baby names, 2nd Ed. Cincinnati, OH: Better Way Books, 1990. 
-England, Paula. "The Failure of Human Capital Theory to Explain Occupational Sex Segregation." Journal of Human Resources, Summer 1982, 17(3), pp. 358-70.

England, Paula; Kilbourne, Barbara Stanek; Farkas, George and Dou, Thomas. "Explaining Occupational Sex Segregation and Wages: Findings from a Model with Fixed Effects." American Sociological Review, August 1988, 53(4), pp. 544-58.

Filer, Randall K. "Occupational Segregation, Compensating Differentials, and Comparable Worth," in Robert T. Michael, Heidi I. Hartmann, and Brigit O'Farrell, eds., Pay equity: Empirical inquiries. Washington, DC: National Academy Press, 1989, pp. 153-70.

Freeman, Richard. "Longitudinal Analyses of the Effects of Trade Unions." Journal of Labor Economics, January 1984, 2(1), pp. $1-26$.

Holzer, Harry and Neumark, David. "Are Affirmative Action Hires Less Qualified? Evidence from Employer-Employee Data on New Hires." National Bureau of Economic Research (Cambridge, MA) Working Paper No. 5603, June 1996.
Hsiao, Cheng. Analysis of panel data. New York: Cambridge University Press, 1986.

Kenney, Genevieve and Wissoker, Douglas A. "An Analysis of the Correlates of Discrimination Facing Young Hispanic Job-Seekers." American Economic Review, June 1994, 84(3), pp. 674-83.

Kolatch, Alfred J. The Jonathan David dictionary of first names. New York: Perigee Books, 1990.

Lansky, Bruce. 35,000+ baby names. New York: Meadowbrook Press, 1995.

-Neumark, David (with Bank, Roy and Van Nort, Kyle D.). "Sex Discrimination in Restaurant Hiring: An Audit Study." Quarterly Journal of Economics, August 1996, 111(3), pp. 915-41.

New York Times. "Vienna Boys' Choir Hands the Baton to a Woman." October 16, 1996.

Polachek, Solomon W. "Occupational Segregation among Women: Theory, Evidence and a Prognosis," in Cynthia B. Lloyd, Emily Andrews, and Curtis Gilroy, eds., Women in the labor market. New York: Columbia University Press, 1979, pp. 137-57.

Seltzer, George. Music matters: The performer and the American Federation of Musicians. Metuchen, NJ: Scarecrow Press, 1989. 


\section{This article has been cited by:}

1. Fernanda Brollo, Ugo Troiano. 2016. What happens when a woman wins an election? Evidence from close races in Brazil. Journal of Development Economics 122, 28-45. [CrossRef]

2. Alexander Buijsrogge, Eva Derous, Wouter Duyck. 2016. Often biased but rarely in doubt: How initial reactions to stigmatized applicants affect interviewer confidence. Human Performance 1-16. [CrossRef]

3. Diana L. Miller. 2016. Gender, Field, and Habitus: How Gendered Dispositions Reproduce Fields of Cultural Production. Sociological Forum 31:2, 330-353. [CrossRef]

4. Vojtěch Bartoš, Michal Bauer, Julie Chytilová, Filip Matějka. 2016. Attention Discrimination: Theory and Field Experiments with Monitoring Information Acquisition. American Economic Review 106:6, 1437-1475. [Abstract] [View PDF article] [PDF with links]

5. Alessandro Acquisti, Curtis Taylor, Liad Wagman. 2016. The Economics of Privacy. Journal of Economic Literature 54:2, 442-492. [Abstract] [View PDF article] [PDF with links]

6. Guillaume Beaulac, Tim Kenyon. 2016. The Scope of Debiasing in the Classroom. Topoi . [CrossRef]

7. Christopher R Matthews. 2016. Exploring the pastiche hegemony of men. Palgrave Communications 2, 16022. [CrossRef]

8. Iris Bohnet, Alexandra van Geen, Max Bazerman. 2016. When Performance Trumps Gender Bias: Joint vs. Separate Evaluation. Management Science 62:5, 1225-1234. [CrossRef]

9. Anthony Heyes, John A. List. 2016. Supply and Demand for Discrimination: Strategic Revelation of Own Characteristics in a Trust Game. American Economic Review 106:5, 319-323. [Abstract] [View PDF article] [PDF with links]

10. Linda M. Dunn-Jensen, Scott Jensen, Mikelle A. Calhoun, Katherine C. Ryan. 2016. Revealing Gender Bias: An Experiential Exercise. Organization Management Journal 13:2, 101-114. [CrossRef]

11. Career Strategies for Women 36-43. [CrossRef]

12. Ana Rute Cardoso, Paulo Guimarães, Pedro Portugal. 2016. What drives the gender wage gap? A look at the role of firm and job-title heterogeneity. Oxford Economic Papers 68:2, 506-524. [CrossRef]

13. Guillaume Beaurain, David Masclet. 2016. Does affirmative action reduce gender discrimination and enhance efficiency? New experimental evidence. European Economic Review . [CrossRef]

14. Luc Bovens. 2016. Selection under Uncertainty: Affirmative Action at Shortlisting Stage: Table 1. Mind 125:498, 421-437. [CrossRef]

15. Magali Fassiotto, Elizabeth Otto Hamel, Manwai Ku, Shelley Correll, Daisy Grewal, Philip Lavori, V.J. Periyakoil, Allan Reiss, Christy Sandborg, Gregory Walton, Marilyn Winkleby, Hannah Valantine. 2016. Women in Academic Medicine: Measuring Stereotype Threat Among Junior Faculty. Journal of Women's Health 25, 292-298. [CrossRef]

16. Alice H. Eagly. 2016. When Passionate Advocates Meet Research on Diversity, Does the Honest Broker Stand a Chance?. Journal of Social Issues 72:1, 199-222. [CrossRef]

17. Sun-Young Park. 2016. A Gender and The Beauty Showed in Politician's Facial Appearance as an Element of Winning in the Election Process. Journal of Digital Convergence 14:2, 397-414. [CrossRef]

18. Robert Legg, David Jeffery. 2016. Suleika and Hatem revisited: uncovering the material advantages of identifying as a male composer. Music Education Research 1-10. [CrossRef]

19. Isabel Fernandez-Mateo, Roberto M. Fernandez. 2016. Bending the Pipeline? Executive Search and Gender Inequality in Hiring for Top Management Jobs. Management Science . [CrossRef]

20. Jurjen J. A. Kamphorst, Otto H. Swank. 2016. Don't Demotivate, Discriminate. American Economic Journal: Microeconomics 8:1, 140-165. [Abstract] [View PDF article] [PDF with links] 
21. Diana L. Miller. 2016. Gender and the Artist Archetype: Understanding Gender Inequality in Artistic Careers. Sociology Compass 10:10.1111/soc4.v10.2, 119-131. [CrossRef]

22. Bentley Coffey, Patrick A. McLaughlin. 2016. The Effect on Lawyers Income of Gender Information Contained in First Names. Review of Law \& Economics, ahead of print. [CrossRef]

23. María Arrazola, José de Hevia. 2016. The Gender Wage Gap in Offered, Observed, and Reservation Wages for Spain. Feminist Economics 1. [CrossRef]

24. Samuel V. Bruton. 2015. Looks-Based Hiring and Wrongful Discrimination. Business and Society Review 120:10.1111/basr.2015.120.issue-4, 607-635. [CrossRef]

25. Aidan Byrne, Alessandra Tanesini. 2015. Instilling new habits: addressing implicit bias in healthcare professionals. Advances in Health Sciences Education 20, 1255-1262. [CrossRef]

26. Bjorn Tyrefors Hinnerich, Erik Höglin, Magnus Johannesson. 2015. Discrimination against students with foreign backgrounds: evidence from grading in Swedish public high schools. Education Economics 23, 660-676. [CrossRef]

27. Thomas Breda, Son Thierry Ly. 2015. Professors in Core Science Fields Are Not Always Biased against Women: Evidence from France. American Economic Journal: Applied Economics 7:4, 53-75. [Abstract] [View PDF article] [PDF with links]

28. Michèle Céline Kaufmann, Franciska Krings, Sabine Sczesny. 2015. Looking Too Old? How an Older Age Appearance Reduces Chances of Being Hired. British Journal of Management n/a-n/a. [CrossRef]

29. Maja Spener. 2015. Calibrating Introspection. Pbilosopbical Issues 25:10.1111/phis.2015.25.issue-1, 300-321. [CrossRef]

30. Ian Ayres, Mahzarin Banaji, Christine Jolls. 2015. Race effects on eBay. The RAND Journal of Economics 46:10.1111/rand.2015.46.issue-4, 891-917. [CrossRef]

31. Andreas Leibbrandt, John A. List. 2015. Do Women Avoid Salary Negotiations? Evidence from a Large-Scale Natural Field Experiment. Management Science 61, 2016-2024. [CrossRef]

32. SIEW CHING GOY, GERAINT JOHNES. 2015. DIFFERENCES IN DECLINE: QUANTILE REGRESSION OF MALE-FEMALE EARNINGS DIFFERENTIAL IN MALAYSIA. The Singapore Economic Review 60, 1550054. [CrossRef]

33. Zheng Fang, Chris Sakellariou. 2015. Glass Ceilings versus Sticky Floors: Evidence from Southeast Asia and an International Update. Asian Economic Journal 29:10.1111/asej.2015.29.issue-3, 215-242. [CrossRef]

34. Matthew A. Kraft. 2015. Teacher Layoffs, Teacher Quality, and Student Achievement: Evidence from a Discretionary Layoff Policy. Education Finance and Policy 1-41. [CrossRef]

35. Lin Xiu, Gerui (Grace) Kang, Alan C. Roline. 2015. Who negotiates a higher starting salary?. Nankai Business Review International 6, 240-255. [CrossRef]

36. Luc Behaghel, Bruno Crépon, Thomas Le Barbanchon. 2015. Unintended Effects of Anonymous Résumés. American Economic Journal: Applied Economics 7:3, 1-27. [Abstract] [View PDF article] [PDF with links]

37. Alex Bryson, Arnaud Chevalier. 2015. Is there a taste for racial discrimination amongst employers?. Labour Economics 34, 51-63. [CrossRef]

38. stephen bates, heather savigny. 2015. introduction: women in european political science. European Political Science 14:2, 75-78. [CrossRef]

39. Christina Scharff. 2015. Blowing your own trumpet: exploring the gendered dynamics of selfpromotion in the classical music profession. The Sociological Review 63, 97-112. [CrossRef]

40. Kenneth S. Rhee, Tracey H. Sigler. 2015. Untangling the relationship between gender and leadership. Gender in Management: An International Journal 30, 109-134. [CrossRef] 
41. Shireen Kanji, Sandra Hupka-Brunner. 2015. Young women's strong preference for children and subsequent occupational gender segregation. Equality, Diversity and Inclusion: An International Journal 34, 124-140. [CrossRef]

42. E. S. Darling. 2015. Use of double-blind peer review to increase author diversity. Conservation Biology 29:10.1111/cobi.2015.29.issue-1, 297-299. [CrossRef]

43. Darlene F. Saporu, Joan M. Herbers. 2015. What's in a Title? Gender Micro-Inequities in a University Human Resources Database. NASPA Journal About Women in Higher Education 8, 101-116. [CrossRef]

44. Kenneth Elpus. 2015. National estimates of male and female enrolment in American high school choirs, bands and orchestras. Music Education Research 17, 88-102. [CrossRef]

45. Maria De Paola, Vincenzo Scoppa. 2015. Gender Discrimination and Evaluators' Gender: Evidence from Italian Academia. Economica 82:10.1111/ecca.2014.82.issue-325, 162-188. [CrossRef]

46. Jan W Peters, Nancy J Lane 1. [CrossRef]

47. Douglas S. MasseyInequality, Social 908-913. [CrossRef]

48. Francine D. BlauGender, Economics of 757-763. [CrossRef]

49. Lekelia Danielle Jenkins. 2015. From conflict to collaboration: The role of expertise in fisheries management. Ocean \& Coastal Management 103, 123-133. [CrossRef]

50. Sophie Ponthieux, Dominique MeursGender Inequality 981-1146. [CrossRef]

51. J. A. Flory, A. Leibbrandt, J. A. List. 2015. Do Competitive Workplaces Deter Female Workers? A Large-Scale Natural Field Experiment on Job Entry Decisions. The Review of Economic Studies 82:1, 122. [CrossRef]

52. Alastair Brown. 2014. Double-blind under review. Nature Nanotechnology 9, 871-872. [CrossRef]

53. Joya Misra, Marta Murray-Close. 2014. The Gender Wage Gap in the United States and Cross Nationally. Sociology Compass 8:10.1111/soc4.v8.11, 1281-1295. [CrossRef]

54. Stijn Baert. 2014. Career lesbians. Getting hired for not having kids?. Industrial Relations Journal 45:10.1111/irj.2014.45.issue-6, 543-561. [CrossRef]

55. Andrea Romei, Salvatore Ruggieri. 2014. A multidisciplinary survey on discrimination analysis. The Knowledge Engineering Review 29, 582-638. [CrossRef]

56. Geoffrey Lightfoot, Tomasz Piotr Wisniewski. 2014. Information asymmetry and power in a surveillance society. Information and Organization 24, 214-235. [CrossRef]

57.2014. Pathways into a Gendered Occupation. International Journal of Social and Organizational Dynamics in IT 2:10.4018/IJSODIT.20121001, 34-51. [CrossRef]

58. Ghazala Azmat, Barbara Petrongolo. 2014. Gender and the labor market: What have we learned from field and lab experiments?. Labour Economics 30, 32-40. [CrossRef]

59. Yuval Arbel, Yossef Tobol, Erez Siniver. 2014. Social involvement, level of income and employment among immigrants. International Journal of Manpower 35, 798-816. [CrossRef]

60. Roberto M. Fernandez, Roman V. GalperinThe Causal Status of Social Capital in Labor Markets 445-462. [CrossRef]

61. HILLARY N. MORGAN, KURT W. ROTTHOFF. 2014. THE HARDER THE TASK, THE HIGHER THE SCORE: FINDINGS OF A DIFFICULTY BIAS. Economic Inquiry 52:10.1111/ ecin.2014.52.issue-3, 1014-1026. [CrossRef]

62. Chia-Jung Tsay. 2014. The vision heuristic: Judging music ensembles by sight alone. Organizational Bebavior and Human Decision Processes 124, 24-33. [CrossRef]

63. Chiara Mussida, Matteo Picchio. 2014. The trend over time of the gender wage gap in Italy. Empirical Economics 46, 1081-1110. [CrossRef] 
64. Stéphane Robin, Agnieszka Rusinowska, Marie Claire Villeval. 2014. Ingratiation: Experimental evidence. European Economic Review 66, 16-38. [CrossRef]

65. References 197-203. [CrossRef]

66. Erin L. Cadwalader, Amanda C. Bryant-FriedrichImproving Transparency and Equity in Scholarly Recognition by Scientific Societies 245-254. [CrossRef]

67. Heather Savigny. 2014. Women, know your limits: cultural sexism in academia. Gender and Education 26:7, 794. [CrossRef]

68. Y. Rubinstein, D. Brenner. 2014. Pride and Prejudice: Using Ethnic-Sounding Names and InterEthnic Marriages to Identify Labour Market Discrimination. The Review of Economic Studies 81, 389-425. [CrossRef]

69. Crystal L. HoytSocial Identities and Leadership: The Case of Gender 71-91. [CrossRef]

70. Paola Profeta, Livia Amidani Aliberti, Alessandra Casarico, Marilisa D’Amico, Anna PuccioQuotas on Boards: Evidence from the Literature 41-67. [CrossRef]

71. Philippe Jacquart, J. Scott Armstrong. 2013. The Ombudsman: Are Top Executives Paid Enough? An Evidence-Based Review. Interfaces 43, 580-589. [CrossRef]

72. Adrian Masters. 2013. Statistical discrimination from composition effects in the market for lowskilled workers. Labour Economics . [CrossRef]

73. Jonathan Guryan, Kerwin Kofi Charles. 2013. Taste-based or Statistical Discrimination: The Economics of Discrimination Returns to its Roots. The Economic Journal 123:10.1111/ ecoj.2013.123.issue-572, F417-F432. [CrossRef]

74. Kristen Monroe. 2013. Tougher Standards for Female Scholars? The Psychology Behind Them and Policies to Eliminate Them. International Studies Perspectives 14:10.1111/insp.2013.14.issue-4, 476-484. [CrossRef]

75. Asaf Zussman. 2013. Ethnic Discrimination: Lessons from the Israeli Online Market for Used Cars. The Economic Journal 123:10.1111/ecoj.2013.123.issue-572, F433-F468. [CrossRef]

76. Chia-Jung Tsay. 2013. Sight over sound in the judgment of music performance. Proceedings of the National Academy of Sciences 110, 14580-14585. [CrossRef]

77. C. Bram Cadsby, Maroš Servátka, Fei Song. 2013. How competitive are female professionals? A tale of identity conflict. Journal of Economic Behavior \& Organization 92, 284-303. [CrossRef]

78. David A. Matsa,, Amalia R. Miller. 2013. A Female Style in Corporate Leadership? Evidence from Quotas. American Economic Journal: Applied Economics 5:3, 136-169. [Abstract] [View PDF article] [PDF with links]

79. Victor Lavy. 2013. Gender Differences in Market Competitiveness in a Real Workplace: Evidence from Performance-based Pay Tournaments among Teachers*. The Economic Journal 123, 540-573. [CrossRef]

80. Giacomo Negro, Ming D. Leung. 2013. “Actual” and Perceptual Effects of Category Spanning. Organization Science 24, 684-696. [CrossRef]

81. Amine Ouazad, Lionel Page. 2013. Students' Perceptions of Teacher Biases: Experimental Economics in Schools. Journal of Public Economics . [CrossRef]

82. Roxana Barbulescu, Matthew Bidwell. 2013. Do Women Choose Different Jobs from Men? Mechanisms of Application Segregation in the Market for Managerial Workers. Organization Science 24, 737-756. [CrossRef]

83. Manuel Bagues, Maria J. Perez-Villadoniga. 2013. Why do I like people like me?. Journal of Economic Theory 148, 1292-1299. [CrossRef] 
84. Calvin K. Lai, Kelly M. Hoffman, Brian A. Nosek. 2013. Reducing Implicit Prejudice. Social and Personality Psychology Compass 7, 315-330. [CrossRef]

85. Eric P. Baumer. 2013. Reassessing and Redirecting Research on Race and Sentencing. Justice Quarterly 30, 231-261. [CrossRef]

86. Robert O. Deaner. 2013. Distance Running as an Ideal Domain for Showing a Sex Difference in Competitiveness. Archives of Sexual Behavior 42, 413-428. [CrossRef]

87. Marco Castillo, Ragan Petrie, Maximo Torero, Lise Vesterlund. 2013. Gender differences in bargaining outcomes: A field experiment on discrimination. Journal of Public Economics 99, 35-48. [CrossRef]

88. Feng Li, Venky Nagar. 2013. Diversity and Performance. Management Science 59, 529-544. [CrossRef]

89. Oscar Afonso. 2013. SCALE-INDEPENDENT TECHNOLOGICAL-KNOWLEDGE BIAS, HUMAN-CAPITAL ACCUMULATION AND GENDER INEQUALITY. Metroeconomica 64:10.1111/meca.2013.64.issue-1, 125-151. [CrossRef]

90. NABANITA DATTA GUPTA, ANDERS POULSEN, MARIE CLAIRE VILLEVAL. 2013. GENDER MATCHING AND COMPETITIVENESS: EXPERIMENTAL EVIDENCE. Economic Inquiry 51:10.1111/ecin.2013.51.issue-1, 816-835. [CrossRef]

91. K. Inman, N. RudinSequential Unmasking: Minimizing Observer Effects in Forensic Science 542-548. [CrossRef]

92. Catherine P. Mulder. 2013. Unions' Resistance to Capital and the Potential for Class Transformation. Retbinking Marxism 25, 114-120. [CrossRef]

93. Muriel Niederle, Carmit Segal, Lise Vesterlund. 2013. How Costly Is Diversity? Affirmative Action in Light of Gender Differences in Competitiveness. Management Science 59, 1-16. [CrossRef]

94. Nicolas Jacquemet, Constantine Yannelis. 2012. Indiscriminate discrimination: A correspondence test for ethnic homophily in the Chicago labor market. Labour Economics 19, 824-832. [CrossRef]

95. Rema N. Hanna, Leigh L. Linden. 2012. Discrimination in Grading. American Economic Journal: Economic Policy 4:4, 146-168. [Abstract] [View PDF article] [PDF with links]

96. Marie-Pierre Dargnies. 2012. Men Too Sometimes Shy Away from Competition: The Case of Team Competition. Management Science 58, 1982-2000. [CrossRef]

97. C. A. Moss-Racusin, J. F. Dovidio, V. L. Brescoll, M. J. Graham, J. Handelsman. 2012. Science faculty's subtle gender biases favor male students. Proceedings of the National Academy of Sciences 109, 16474-16479. [CrossRef]

98. Stefan Eriksson, Jonas Lagerström. 2012. Detecting discrimination in the hiring process: evidence from an Internet-based search channel. Empirical Economics 43, 537-563. [CrossRef]

99. Tessa V. West, Madeline E. Heilman, Lindy Gullett, Corinne A. Moss-Racusin, Joe C. Magee. 2012. Building blocks of bias: Gender composition predicts male and female group members' evaluations of each other and the group. Journal of Experimental Social Psychology 48, 1209-1212. [CrossRef]

100. Juan J. Dolado, Florentino Felgueroso, Miguel Almunia. 2012. Are men and women-economists evenly distributed across research fields? Some new empirical evidence. SERIEs 3, 367-393. [CrossRef]

101. Nilanjana Dasgupta, Jane G. Stout. 2012. Contemporary Discrimination in the Lab and Field: Benefits and Obstacles of Full-Cycle Social Psychology. Journal of Social Issues 68, 399-412. [CrossRef]

102. Marc Bendick, Ana P. Nunes. 2012. Developing the Research Basis for Controlling Bias in Hiring. Journal of Social Issues 68:10.1111/josi.2012.68.issue-2, 238-262. [CrossRef]

103. Lisa D. Cook. 2012. Overcoming Discrimination by Consumers during the Age of Segregation: The Example of Garrett Morgan. Business History Review 86, 211-234. [CrossRef] 
104. OLGA ALONSO-VILLAR, CORAL DEL RIO, CARLOS GRADIN. 2012. The Extent of Occupational Segregation in the United States: Differences by Race, Ethnicity, and Gender. Industrial Relations: A Journal of Economy and Society 51:10.1111/irel.2012.51.issue-2, 179-212. [CrossRef]

105. Petra Moser. 2012. Taste-based discrimination evidence from a shift in ethnic preferences after WWI. Explorations in Economic History 49, 167-188. [CrossRef]

106. Leng Lee. 2012. Decomposing wage differentials between migrant workers and urban workers in urban China's labor markets. China Economic Review . [CrossRef]

107. Brian A. Nosek, Rachel G. Riskind. 2012. Policy Implications of Implicit Social Cognition. Social Issues and Policy Review 6:10.1111/sipr.2012.6.issue-1, 113-147. [CrossRef]

108. L. Balafoutas, M. Sutter. 2012. Affirmative Action Policies Promote Women and Do Not Harm Efficiency in the Laboratory. Science 335, 579-582. [CrossRef]

109. Thomas Cornelissen, Uwe Jirjahn. 2012. September 11th and the earnings of Muslims in Germany - The moderating role of education and firm size. Journal of Economic Bebavior \& Organization 81, 490-504. [CrossRef]

110. Hannah Riley Bowles. 2012. Claiming authority: How women explain their ascent to top business leadership positions. Research in Organizational Bebavior 32, 189-212. [CrossRef]

111. Richard F. Martell, Cynthia G. Emrich, James Robison-Cox. 2012. From bias to exclusion: A multilevel emergent theory of gender segregation in organizations. Research in Organizational Behavior 32, 137-162. [CrossRef]

112. Fredrik Carlsson, Åsa Löfgren, Thomas Sterner. 2012. Discrimination in Scientific Review: A Natural Field Experiment on Blind versus Non-Blind Reviews*. The Scandinavian Journal of Economics nono. [CrossRef]

113. Wei Zhao, Xueguang Zhou. 2011. Status Inconsistency and Product Valuation in the California Wine Market. Organization Science 22, 1435-1448. [CrossRef]

114. Philip Oreopoulos. 2011. Why Do Skilled Immigrants Struggle in the Labor Market? A Field Experiment with Thirteen Thousand Resumes. American Economic Journal: Economic Policy 3:4, 148-171. [Abstract] [View PDF article] [PDF with links]

115. Amy J.C. Cuddy, Peter Glick, Anna Beninger. 2011. The dynamics of warmth and competence judgments, and their outcomes in organizations. Research in Organizational Bebavior . [CrossRef]

116. Shamena Anwar. 2011. Testing for Discrimination: Evidence from the Game Show Street Smarts. Journal of Economic Behavior \& Organization . [CrossRef]

117. Muriel Niederle, Lise Vesterlund. 2011. Gender and Competition. Annual Review of Economics 3, 601-630. [CrossRef]

118. Kerwin Kofi Charles, Jonathan Guryan. 2011. Studying Discrimination: Fundamental Challenges and Recent Progress. Annual Review of Economics 3, 479-511. [CrossRef]

119. Maria Charles. 2011. A World of Difference: International Trends in Women's Economic Status. Annual Review of Sociology 37, 355-371. [CrossRef]

120. Martín Moreno, Hugo Nopo, Jaime Saavedra, Máximo Torero. 2011. Detecting Gender and Racial Discrimination in Hiring through Monitoring Intermediation Services: The Case of Selected Occupations in Metropolitan Lima, Peru. World Development . [CrossRef]

121. D. James Greiner, Donald B. Rubin. 2011. Causal Effects of Perceived Immutable Characteristics. Review of Economics and Statistics 93, 775-785. [CrossRef]

122. David M. Waguespack, Olav Sorenson. 2011. The Ratings Game: Asymmetry in Classification. Organization Science 22, 541-553. [CrossRef] 
123. Sally Chapman, Felicia F. Dixon, Natalie Foster, Valerie J. Kuck, Deborah A. McCarthy, Nancy M. Tooney, Janine P. Buckner, Susan A. Nolan, Cecilia H. Marzabadi. 2011. Female Faculty Members in University Chemistry Departments: Observations and Conclusions Based on Site Visits. Journal of Chemical Education 88, 716-720. [CrossRef]

124. SUBHASISH DUGAR, HAIMANTI BHATTACHARYA, DAVID REILEY. 2011. CAN'T BUY ME LOVE? A FIELD EXPERIMENT EXPLORING THE TRADE-OFF BETWEEN INCOME AND CASTE-STATUS IN AN INDIAN MATRIMONIAL MARKET. Economic Inquiry no-no. [CrossRef]

125. C. R. Taylor, H. Yildirim. 2011. Subjective Performance and the Value of Blind Evaluation. The Review of Economic Studies 78, 762-794. [CrossRef]

126. Chia-Jung Tsay, Mahzarin R. Banaji. 2011. Naturals and strivers: Preferences and beliefs about sources of achievement. Journal of Experimental Social Psychology 47, 460-465. [CrossRef]

127. Leo Kaas, Christian Manger. 2011. Ethnic Discrimination in Germany's Labour Market: A Field Experiment. German Economic Review no-no. [CrossRef]

128. S. J. Ceci, W. M. Williams. 2011. Understanding current causes of women's underrepresentation in science. Proceedings of the National Academy of Sciences 108, 3157-3162. [CrossRef]

129. Timothy S. Simcoe, Dave M. Waguespack. 2011. Status, Quality, and Attention: What's in a (Missing) Name?. Management Science 57, 274-290. [CrossRef]

130. Barbara Bonnekessen. 2011. The NSF Career-Life Balance Initiative: A Critical Examination. Journal of Workplace Rights 16, 299-313. [CrossRef]

131. John A. List, Imran RasulField Experiments in Labor Economics 103-228. [CrossRef]

132. Timo Gnambs, Bernad Batinic. 2011. Evaluation of measurement precision with Rasch-type models: The case of the short Generalized Opinion Leadership Scale. Personality and Individual Differences 50, 53-58. [CrossRef]

133. Benjamin L. Solow, John L. Solow, Todd B. Walker. 2010. Moving on up: The Rooney rule and minority hiring in the NFL\#. Labour Economics . [CrossRef]

134. MANUEL F. BAGUES, BERTA ESTEVE-VOLART. 2010. Can Gender Parity Break the Glass Ceiling? Evidence from a Repeated Randomized Experiment. Review of Economic Studies 77:10.1111/ roes.2010.77.issue-4, 1301-1328. [CrossRef]

135. Lars Bo Jeppesen, Karim R. Lakhani. 2010. Marginality and Problem-Solving Effectiveness in Broadcast Search. Organization Science 21, 1016-1033. [CrossRef]

136. Guy Michaels,, Xiaojia Zhi. 2010. Freedom Fries. American Economic Journal: Applied Economics 2:3, 256-281. [Abstract] [View PDF article] [PDF with links]

137. Crystal L. Hoyt. 2010. Women, Men, and Leadership: Exploring the Gender Gap at the Top. Social and Personality Psychology Compass 4, 484-498. [CrossRef]

138. Diana Bilimoria, Kimberly Buch. 2010. The Search is On: Engendering Faculty Diversity Through More Effective Search and Recruitment. Change: The Magazine of Higher Learning 42, 27-32. [CrossRef]

139. Markus Gangl. 2010. Causal Inference in Sociological Research. Annual Review of Sociology 36, 21-47. [CrossRef]

140. PAOLA SAPIENZA. 2010. Discussion of Self-Selection and the Forecasting Abilities of Female Equity Analysts. Journal of Accounting Research 48:10.1111/joar.2010.48.issue-2, 437-443. [CrossRef]

141. Destiny Peery, Jennifer Richeson. 2010. Broadening Horizons: Considerations for Creating a More Complete Science of Diversity. Psychological Inquiry 21, 146-152. [CrossRef]

142. Vincent Yzerbyt, Stéphanie Demoulin . [CrossRef] 
143. Arthur Eisenkraft. 2010. Millikan Lecture 2009: Physics for all: From special needs to Olympiads. American Journal of Physics 78, 328. [CrossRef]

144. Stephanie Riegg Cellini, Signe-Mary McKernan, Caroline Ratcliffe. 2009. The dynamics of poverty in the United States: A review of data, methods, and findings. Journal of Policy Analysis and Management 27:10.1002/pam.v27:3, 577-605. [CrossRef]

145. Deborah M. Kolb. 2009. Too Bad for the Women or Does It Have to Be? Gender and Negotiation Research over the Past Twenty-Five Years. Negotiation Journal 25:10.1111/nejo.2009.25.issue-4, 515-531. [CrossRef]

146. Nicola Persico. 2009. Racial Profiling? Detecting Bias Using Statistical Evidence. Annual Review of Economics 1, 229-254. [CrossRef]

147. K. Anders Ericsson, Kiruthiga Nandagopal, Roy W. Roring. 2009. Toward a Science of Exceptional Achievement. Annals of the New York Academy of Sciences 1172, 199-217. [CrossRef]

148. MARLENE KIM. 2009. Race and Gender Differences in the Earnings of Black Workers. Industrial Relations: A Journal of Economy and Society 48:10.1111/irel.2009.48.issue-3, 466-488. [CrossRef]

149. Susan Sturm. 2009. Negotiating Workplace Equality: A Systemic Approach. Negotiation and Conflict Management Research 2:10.1111/ncmr.2009.2.issue-1, 92-106. [CrossRef]

150. MADELINE E. HEILMAN, ALICE H. EAGLY. 2008. Gender Stereotypes Are Alive, Well, and Busy Producing Workplace Discrimination. Industrial and Organizational Psychology 1:10.1111/ iops.2008.1.issue-4, 393-398. [CrossRef]

151. Robert L. Nelson, Ellen C. Berrey, Laura Beth Nielsen. 2008. Divergent Paths: Conflicting Conceptions of Employment Discrimination in Law and the Social Sciences. Annual Review of Law and Social Science 4, 103-122. [CrossRef]

152. Tim Dare, Justine Kingsbury. 2008. Putting the Burden of Proof in Its Place: When Are Differential Allocations Legitimate?. The Southern Journal of Philosopby 46:10.1111/sjp.2008.46.issue-4, 503-518. [CrossRef]

153. RAYMOND PATERNOSTER, ROBERT BRAME. 2008. REASSESSING RACE DISPARITIES IN MARYLAND CAPITAL CASES*. Criminology 46:10.1111/crim.2008.46.issue-4, 971-1008. [CrossRef]

154. C. Elizabeth Hirsh, Youngjoo Cha. 2008. Understanding Employment Discrimination: A Multilevel Approach. Sociology Compass 2:10.1111/soco.2008.2.issue-6, 1989-2007. [CrossRef]

155. Tanya S. Rosenblat. 2008. The Beauty Premium: Physical Attractiveness and Gender in Dictator Games. Negotiation Journal 24:10.1111/nejo.2008.24.issue-4, 465-481. [CrossRef]

156. Fiona Greig. 2008. Propensity to Negotiate and Career Advancement: Evidence from an Investment Bank that Women Are on a "Slow Elevator". Negotiation Journal 24:10.1111/nejo.2008.24.issue-4, 495-508. [CrossRef]

157. Muriel Niederle, Lise Vesterlund. 2008. Gender Differences in Competition. Negotiation Journal 24:10.1111/nejo.2008.24.issue-4, 447-463. [CrossRef]

158. Catherine Eckel, Angela C. M. de Oliveira, Philip J. Grossman. 2008. Gender and Negotiation in the Small: Are Women (Perceived to Be) More Cooperative than Men?. Negotiation Journal 24:10.1111/ nejo.2008.24.issue-4, 429-445. [CrossRef]

159. Claudia S. Morrissey, Mary Lou Schmidt. 2008. Fixing the System, Not the Women: An Innovative Approach to Faculty Advancement. Journal of Women's Health 17, 1399-1408. [CrossRef]

160. Melissa J. Williams, Gerald A. Mendelsohn. 2008. Gender Clues and Cues: Online Interactions as Windows into Lay Theories about Men and Women. Basic and Applied Social Psychology 30, 278-294. [CrossRef] 
161. Catherine Loughlin, Kara A. Arnold. 2008. Seeking the best: Leadership lessons from the military. Human Resource Management 46:10.1002/hrm.v46:1, 147-167. [CrossRef]

162. THOMAS J. DOHMEN. 2008. THE INFLUENCE OF SOCIAL FORCES: EVIDENCE FROM THE BEHAVIOR OF FOOTBALL REFEREES. Economic Inquiry 46:10.1111/ ecin.2008.46.issue-3, 411-424. [CrossRef]

163. David Bjerk. 2008. Glass Ceilings or Sticky Floors? Statistical Discrimination in a Dynamic Model of Hiring and Promotion*. The Economic Journal 118:10.1111/ecoj.2008.118.issue-530, 961-982. [CrossRef]

164. SALLY HASLANGER. 2008. Changing the Ideology and Culture of Philosophy: Not by Reason (Alone). Hypatia 23, 210-223. [CrossRef]

165. Sally Haslanger. 2008. Changing the Ideology and Culture of Philosophy: Not by Reason (Alone). Hypatia: A Journal of Feminist Philosophy 23:10.2979/hyp.2008.23.issue-2, 210-223. [CrossRef]

166. David H. Autor, David Scarborough. 2008. Does Job Testing Harm Minority Workers? Evidence from Retail Establishments *. Quarterly Journal of Economics 123:10.1162/qjec.2008.123.issue-1, 219-277. [CrossRef]

167. A JONES, K FRICK. 2008. Gender Bias in Economic Evaluation MethodsTime Costs and Productivity Loss. Women's Health Issues 18, 1-3. [CrossRef]

168. Arnaud Chevalier. 2007. Education, Occupation and Career Expectations: Determinants of the Gender Pay Gap for UK Graduates. Oxford Bulletin of Economics and Statistics 69:10.1111/ obes.2007.69.issue-6, 819-842. [CrossRef]

169. Annick Vignes, Olivier Gergaud. 2007. Twilight of the Idols in the Market for Champagne: Dissonance or Consonance in Consumer Preferences?. Journal of Wine Research 18, 147-162. [CrossRef]

170. Judith L. Komaki. 2007. Daring to Dream: Promoting Social and Economic Justice at Work. Applied Psychology 56:10.1111/apps.2007.56.issue-4, 624-662. [CrossRef]

171. Muriel Niederle, Lise Vesterlund. 2007. Do Women Shy Away from Competition? Do Men Compete Too Much?*. Quarterly Journal of Economics 122:10.1162/qjec.2007.122.issue-3, 1067-1101. [CrossRef]

172. K. Anders Ericsson, Roy W. Roring, Kiruthiga Nandagopal. 2007. Giftedness and evidence for reproducibly superior performance: an account based on the expert performance framework. High Ability Studies 18, 3-56. [CrossRef]

173. John J. DonohueChapter 18 Antidiscrimination Law 1387-1472. [CrossRef]

174. Niki T. Dickerson. 2006. "WE ARE A FORCE TO BE RECKONED WITH": BLACK AND LATINA WOMEN'S LEADERSHIP IN THE CONTEMPORARY U.S. LABOR MOVEMENT. WorkingUSA 9:10.1111/wusa.2006.9.issue-3, 293-313. [CrossRef]

175. Evalyn Gates. 2006. A scientific point of view. Physics Today 59, 64-65. [CrossRef]

176. Markus M. Mobius, Tanya S. Rosenblat. 2006. Why Beauty Matters. American Economic Review 96:1, 222-235. [Abstract] [View PDF article] [PDF with links]

177. Morley Gunderson. 2006. Viewpoint: Male-female wage differentials: how can that be?. Canadian Journal of Economics/Revue canadienne d'<btml_ent glyph="@eacute;" ascii="e"/>conomique 39:10.1111/ caje.2006.39.issue-1, 1-21. [CrossRef]

178. Neil O. Alper, Gregory H. WassallChapter 23 Artists' Careers and Their Labor Markets 813-864. [CrossRef]

179. TROND PETERSEN, ISHAK SAPORTA, MARC-DAVID L. SEIDEL. 2005. Getting Hired: Sex and Race. Industrial Relations 44:10.1111/irel.2005.44.issue-3, 416-443. [CrossRef] 
180. Luis Garicano, Ignacio Palacios-Huerta, Canice Prendergast. 2005. Favoritism Under Social Pressure. Review of Economics and Statistics 87, 208-216. [CrossRef]

181. Esther Duflo. 2005. Why Political Reservations?. Journal of the European Economic Association 3:10.1162/jeea.2005.3.issue-2-3, 668-678. [CrossRef]

182. Barbara F. Reskin, Denise D. Bielby. 2005. A Sociological Perspective on Gender and Career Outcomes. Journal of Economic Perspectives 19:1, 71-86. [Abstract] [View PDF article] [PDF with links]

183. Robin E. Bell, Jennifer D. Laird. 2005. Women, Work, and the Academy. Eos, Transactions American Geophysical Union 86. . [CrossRef]

184. Marianne Bertrand, Sendhil Mullainathan. 2004. Are Emily and Greg More Employable Than Lakisha and Jamal? A Field Experiment on Labor Market Discrimination. American Economic Review 94:4, 991-1013. [Abstract] [View PDF article] [PDF with links]

185. Uri Gneezy, Aldo Rustichini. 2004. Gender and Competition at a Young Age. American Economic Review 94:2, 377-381. [Citation] [View PDF article] [PDF with links]

186. John A. List. 2004. The Nature and Extent of Discrimination in the Marketplace: Evidence From the Field*. Quarterly Journal of Economics 119:10.1162/qjec.2004.119.issue-1, 49-89. [CrossRef]

187. Trond Petersen, Ishak Saporta. 2004. The Opportunity Structure for Discrimination. American Journal of Sociology 109:10.1086/ajs.2004.109.issue-4, 852-901. [CrossRef]

188. Judea Pearl. 2003. Statistics and causal inference: A review. Test 12, 281-345. [CrossRef]

189. David Neumark. 2003. Age Discrimination Legislation in the United States. Contemporary Economic Policy 21, 297-317. [CrossRef]

190. Kaivan Munshi. 2003. Networks in the Modern Economy: Mexican Migrants in the U.S. Labor Market*. Quarterly Journal of Economics 118:10.1162/qjec.2003.118.issue-2, 549-599. [CrossRef]

191. W. Bentley Macleod. 2003. Optimal Contracting with Subjective Evaluation. American Economic Review 93:1, 216-240. [Abstract] [View PDF article] [PDF with links]

192. Victor A. Ginsburgh, Jan C. van Ours. 2003. Expert Opinion and Compensation: Evidence from a Musical Competition. American Economic Review 93:1, 289-296. [Citation] [View PDF article] [PDF with links]

193. P. A. Riach, J. Rich. 2002. Field Experiments of Discrimination in the Market Place*. The Economic Journal 112:10.1111/ecoj.2002.112.issue-483, F480-F518. [CrossRef]

194. Erik D. Craft. 2002. THE DEMAND FOR VANITY (PLATES): ELASTICITIES, NET REVENUE MAXIMIZATION, AND DEADWEIGHT LOSS. Contemporary Economic Policy 20, 133-144. [CrossRef]

195. F.D. BlauGender, Economics of 5995-6002. [CrossRef]

196. Francine D. Blau, Lawrence M. Kahn,. 2000. Gender Differences in Pay. Journal of Economic Perspectives 14:4, 75-100. [Abstract] [View PDF article] [PDF with links]

197. Trond Petersen, Ishak Saporta, Marc-David L. Seidel. 2000. Offering a Job: Meritocracy and Social Networks. American Journal of Sociology 106:10.1086/ajs.2000.106.issue-3, 763-816. [CrossRef]

198. Brenda ParkerBeyond the class act: Gender and race in the 'creative city' discourse 201-232. [CrossRef]

199. Denise Lewin Loyd, Katherine W. PhillipsManaging Perceptions of Ethical Behavior in Evaluative Groups: The Implications for Diversity in Organizations 225-245. [CrossRef] 